This item was submitted to Loughborough's Research Repository by the author.

Items in Figshare are protected by copyright, with all rights reserved, unless otherwise indicated.

\title{
The antecedents of corporate entrepreneurship: multilevel, multisource evidence
}

PLEASE CITE THE PUBLISHED VERSION

https://doi.org/10.1007/s11846-021-00447-y

PUBLISHER

Springer

VERSION

AM (Accepted Manuscript)

\section{PUBLISHER STATEMENT}

This is a post-peer-review, pre-copyedit version of an article published in Review of Managerial Science. The final authenticated version is available online at: https://doi.org/10.1007/s11846-021-00447-y.

\section{LICENCE}

CC BY-NC-ND 4.0

\section{REPOSITORY RECORD}

Chang, Yi-Ying, Paul Hughes, lan Hodgkinson, Che-Yuan Chang, and Yi-Tai Seih. 2021. "The Antecedents of Corporate Entrepreneurship: Multilevel, Multisource Evidence”. Loughborough University. https://hdl.handle.net/2134/13603064.v1. 
The antecedents of corporate entrepreneurship: multilevel, multisource evidence

\section{Yi-Ying Chang}

National Taiwan University of Science and Technology, Department of Business

Administration, 43 Keelung Road, Section 4, Taipei 106, Taiwan

e: y.chang@mail.ntust.edu.tw

\section{Paul Hughes}

De Montfort University, Leicester Castle Business School, Leicester LE1 5WH, United Kingdom t: +44 (0)116 2257 7031, e: paul.hughes@dmu.ac.uk

\section{Ian Hodgkinson}

Loughborough University, School of Business and Economics, Loughborough, Leicestershire LE11 3TU, United Kingdom t: +44 (0)1509 223865, e: I.R.Hodgkinson@lboro.ac.uk

\section{Che-Yuan Chang}

National Taiwan University of Science and Technology, Department of Business Administration, 43 Keelung Road, Section 4, Taipei 106, Taiwan e: a161622@gmail.com

\section{Yi-Tai Seih}

National Taiwan University of Science and Technology, Department of Business Administration, 43 Keelung Road, Section 4, Taipei 106, Taiwan e: yitaiseih@gmail.com

Acknowledgments: This paper originated from a project that was partially funded by the Ministry of Science and Technology of Taiwan, grant number MOST107-2410-H011-023-MY3. We are grateful for their financial contribution.

Corresponding author: Yi-Ying Chang, National Taiwan University of Science and Technology, Department of Business Administration,

Email: y.chang@mail.ntust.edu.tw 


\section{Abstract}

This study employed a resource-based view to develop a multilevel model of firm-level highperformance work systems, dyad-level human capital, firm-level bridging ties and unit-level corporate entrepreneurship. We collected multisource and multilevel data from 420 senior managers, 1260 managers and 3348 employees of 210 units from 96 Taiwanese manufacturing and service sectors firms. The results revealed that dyad-level human capital partially mediated the relationship between firm-level high-performance work systems and unit-level corporate entrepreneurship and firm-level bridging ties moderated the effect of firm-level high-performance work systems on unit-level corporate entrepreneurship through dyad-level human capital. Our findings contribute to corporate entrepreneurship by exploring its antecedent and indirect effect from a resource-based perspective Furthermore, we have found that the indirect influence of firm-level high-performance work systems and unit-level corporate entrepreneurship varies as a function of the bridging ties at the firm level. This paper advances existing research by offering new insights in the area of corporate entrepreneurship.

Keywords Corporate entrepreneurship • High performance work systems • Bridging ties $•$ Human capital $・$ Resource-based view

\section{JEL Classification L26}




\section{Introduction}

There has been growing interest by Human resources (HR) scholars in the impact of high performance work systems (HPWS) (Wright and Ulrich 2017). HPWS provides opportunities for firms and employees to concentrate on organizational innovation by offering autonomy and interactions among individuals (Li et al. 2018; Zhou et al. 2019). Research in the realm of corporate entrepreneurship (CE) also indicate that a firm's HPWS (Hayton 2005; Mustafa et al. 2016; Wright and McMahan 1992) may facilitate the occurrence of CE. CE refers to innovation, venturing, and strategic renewal (Ling et al. 2008). Studies on the $\mathrm{CE}$ revealed that the majority of empirical findings of $\mathrm{CE}$ used various theoretical lens, such as cognition, psychology, social network perspectives (Marvel et al. 2016; Unger et al. 2011) to explore the direct effect of human capital on CE. However, there is little research on of the indirect effect of human capital and social ties such as bridging ties on CE. Human capital refers to knowledge, skill and others (KSAOs) higher order concepts including general and specific human capital (Becker 1964). Bridging ties refers to a type of social capial how a firm network connects with other industries and government officials (Geletkanycz and Hambrick 1997). Both human capital and bridging ties are seen as the most important resources for $\mathrm{CE}$ (Ireland et al. 2003) and are vital to $\mathrm{CE}$ due to the fact that $\mathrm{CE}$ is a "multifaceted phenomenon that cuts across disciplinary boundaries - often benefiting from multiple theoretical lens" (Marvel et al. 2016: 600). Following prior research (e.g. Marvel et al. 2016), we adopted a resource-based view (RBV) (Barney 1991; Ireland et al. 2003; Nyberg et al. 2014) to form a coherent single theoretical framework. RBV emphasizes the importance of valuable, rare, inimitable, and non- 
substitute resources such as human capital and bridging ties (Stam and Elfring 2008) in organisations. These resources are deeply embedded in a firm's resulting in difficulty imitating them (Day 1994). Firms can utilize these resources (i.e. human capital and bridging ties) to drive innovation through the HR practices including recruiting, training and development, etc. To RBV scholars, the firm-specific knowledge is tied together by human resources and employees' commitments in an organizational system (i.e. firm-level HPWS) (Alvarez and Busenitz 2001). To dynamic capability theorists, firm-level CE is considered as an antecedent of human capital and social capital at single level (Simsek and Harvey 2011). In contrast, unit-level CE needs to be driven by resources. These resources are bundled from the HPWS in a firm. Therefore, we argue that RBV rather than the dynamic capability perspective better explains the intermediate link and boundary condition of firm-level HPWS and unit-level CE. Nevertheless, "organizational capital (i.e. human capital and bridging ties)" may be positively related to CE (e.g, Simsek and Harvey 2011). However, not all capital across organizational levels operate in the same way (e.g. Nyberg et al. 2014). Surprisingly, little research explored how embedded internal bridging ties influences human capital potential of a firm's CE at other hierarchical levels in a firm (e.g. Covin and Slevin 1991; Zhang and Jia 2010). In addition, bridging ties could enhance performance of new ventures (Stam and Elfring 2008). Thus, exploring a boundary context under which particular relationships reinforce or suppress firm-level HPWS and unit-level CE represents an important research agenda (Covin and Slevin 1991; Davidsson and Wiklund 2001; Tang et al. 2015). We adopt RBV to explain that dyadlevel human capital mediates the influence of firm-level HPWS and unit-level CE. The cause of using 
dyad-level human capital is that the results of prior studies regarding influences of human capital from different levels and different theoretical perspectives such as RBV are inconsistent (e.g. Nyberg et al. 2014). Additionally, the RBV suggests that the bridging ties is an important social resource as it establishes a context reinforcing the relationship between the firm-level HR practices and the outcomes across levels (Nahapiet and Ghoshal 1998; Subramaniam and Youndt 2005). But, it is not clear if we can use RBV to explicate how and why firm-level bridging ties moderates that dyad-level human capital mediates the effect of firm-level HPWS and unit-level CE. According to previous studies (e.g. Cooke 2018; Stam and Elfring 2008), we suggest that firm-level bridging ties is considered as a contextual variable (i.e., moderator). The importance of interpersonal interaction acquired knowledge externally is to stimulate or impede innovation, venturing and strategic renewal activities (Lavie 2006). By responding to the call for more research into the role of bridging ties (Gedajlovic et al. 2013; Nyberg et al. 2014; Payne et al. 2011), our research explores that firm-level bridging ties moderates firm-level HPWS on unit-level CE by dyad-level human capital. Following the RBV perspective, the nature of firm-level bridging ties will affect a unit's innovation, venturing and strategic renewal activities (Schmelter et al. 2010). We contend that the firm-level bridging ties may either stimulate or restrain a unit's activity on CE. Also, the nature of unit-level CE is the collective value located in the social relationships (Adler and Kwon 2002), so we suggest that the firm-level bridging ties acts as the moderator between firm-level HPWS on unit-level CE by dyad-level human capital. In sum, this study adopts a RBV perspective to argue that firm-level HR practices are perceived as a bundle of organizational resources to stimulate 
innovative and entrepreneurial actions at the lower level of organizational units through dyad-level human capital and such mediating link will be strengthened when a firm establishes a valuable social bridging ties. Figure 1 presents our theoretical framework.

[Fig. 1 here]

The research makes several theoretical contributions. First, it aims to expand our understanding of SHRM and the RBV literature by exploring the "black box" and the boundary conditions between HPWS and $\mathrm{CE}$ across levels. Echoing the prior call for research into the mediating mechanism of dyad-level human capital (Schmelter et al. 2010), this study extends prior research (Gedajlovic et al. 2013) by revealing that the lack of bridging ties as a situational enhancer may lead to the reluctance of employees to engage in the pursuit of innovation. Second, we extended the previous entrepreneurship research by exploring RBV in network resources (e.g. McEvily and Zaheer 1999). Third, supporting the notion that social resources such as bridging ties has contingent value (Ahuja 2000), this study also shows that value creation implications of particular network arrangements can reinforce the indirect influence of human resources, i.e. dyad human capital, between firm-level and unit-level CE. The result underscores the need to examine not only the indirect relationship among collective dyad human capital path, but also the contingencies that determines the situational influence of bridging ties. Fourth, we hope to advance existing literature dialogues for human resource management and entrepreneurship research by investigating empirical data in both manufacturing and services firms.

\section{Theory and hypothesis}


The SHRM literature shows how HPWS is related to various outcomes (e.g. performance (Chen et al.

2016; Fu et al. 2017; Han et al. 2019; Ho and Kuvaas 2020; Hong et al. 2016; Ivars and Martínez 2015;

Jiang et al. 2015; Lin and Liu 2016; Pak and Kim 2018; Salas-Vallina et al. 2020; Shin and Konrad 2017;

Tsao et al. 2016), creativity (Liu et al. 2017), innovation (Donate et al. 2016; Fu et al. 2017; Li et al.

2018; Liu et al. 2017; Marvel et al. 2016; Mom et al. 2019; Prieto-Pastor and Martin-Perez 2015; Zhou

et al. 2019), retention (Pittino et al. 2016), organizational citizenship behaviors (Liu and Lin, 2019)).

However, scant research (e.g. Mustafa et al. 2016; Tang et al. 2015) explores the relationship between

HPWS and CE.

Previous studies used various perspectives such as RBV (Hong et al. 2016; Jiang et al. 2015;

Kaufman 2015a; Lu et al. 2015; Shin and Konrad 2017; Wright and McMahan 1992), Ability-

Motivation-Opportunity (AMO) framework (Ho and Kuvaas 2020; Kaufman 2015a; Mom et al. 2019;

Shin and Konrad 2017; Su et al. 2018), human capital theory (i.e. KSAOs) (Jiang et al. 2015; Kaufman

2015a; Lin and Liu 2016; Su et al. 2018; Wright and Ulrich 2017), intellectual capital-based view

(Donate et al. 2016), dynamic capability perspective (Fu et al. 2017), social exchange theory (Lin and

Liu 2016; Mustafa et al. 2016; Ostroff and Bowen 2016; Wright and Ulrich 2017) to inform the black

boxes linking HPWS and outcomes.

We contend that selections of potential talents (i.e. employees' ability) are based on resources of a firm (Mazzei et al. 2016; Mom et al. 2019; Shin and Konrad 2017). Together, opportunities (Mom et al.

2019; Shin and Konrad 2017), goal setting, commitment (e.g. perfect procedures of staffing and training, 
greater discretion, rewards and incentives, horizontal organizations, and long-term employment) and feedback (Mazzei et al. 2016) are also rooted in these resources of a firm. Additionally, employees' motivation is linked to organizational hiring talents because their motivation is associated with these human capital resources of a firm (Mom et al. 2019; Shin and Konrad 2017). Indeed, employees' KSAOs (i.e. human capital) are also organizational resources and assets (Kaufman 2015a) to gain rents (Wright and Ulrich 2017). Indeed, the AMO framework and human capital theory are associated to the RBV by providing firms the HRM tools to produce high value through empowering employees and to maintain these valuable resources by instituting firm-specific rare, inimitable, and non-reproducible characteristics such as professional training, special benefit plans, performance appraisal, job enrichment and involvement to integrate the HPWS of a firm (Kaufman 2015a). We suggest that the AMO of members are embedded by human capital. These are essential resources for an organization to stimulate generation, transformation, promotion and realization of novel ideas (i.e. CE) (Zhou et al. 2019), venturing and strategic renewal (Kleinknecht 2015; Pohler and Luchak 2015).

The intellectual-based view focuses on how intangible assets that firms acquire, develop and gather and over time change to produce economic rents, and then exhibit better performance than competitors (Reed et al. 2006). Human capital, social capital and organizational capital are part of intellectual capital (Subramaniam and Youndt 2005). Donate et al. (2016) reveal that organization capital includes the collected knowledge of organizational hierarchies, procedures and systems will promote or hinder the relationship between HPWS and CE. We suggest that organization capital may be a boundary condition 
to influence HPWS and innovation. We argue that HPWS, human capital, bridging ties are firm-specific resources rather than non-specific resources. Bridging ties have a contingent value (Ahuja 2000; Zhou et al. 2019) that determines the situational influence of HPWS and innovation.

Nevertheless, scholars of slack resources and adaptive perspective contend the possibility of reversed causality between HPWS and performance (Shin and Konrad 2017). Researchers of general systems theory argue that a reciprocal feedback cycle of the relationship between HPWS and outcomes. Researchers of general systems theory suggest that HPWS is a feedback cycle system rather than a directional system that RBV scholars contend (Shin and Konrad 2017). Following RBV perspective, HPWS is a system of valuable, rare, inimitable, and non-substitute resources that incorporate firmspecific knowledge (Alvarez and Busenitz 2001; Barney 1991). That is, HPWS can be viewed as a bundle of organizational resources to facilitate a firm's innovation-taking and strategical renewal activities (i.e., CE activities).

Schuler and MacMillan (1984) proposed the potential for capitalizing on superior human resource management as a way of pursuing a competitive advantage and then foster new products and services. For RBV, the assumption of competitive advantage in a firm is that a firm owns a resource to produce rents and acquire rents (Wright and Ulrich 2017). The conceptual core of RBV is economic rents (Wright and Ulrich 2017). Rents refer to resource value beyond costs (Wright and Ulrich 2017). The RBV contends that the firm's competitive advantages decide from valuable, rare, imitable, and nonsubstitutable resources (Fu et al. 2017). HPWS is not a direct effect on the influence of competitive 
advantage (Fu et al. 2017). In turn, competitive advantages are obtained from practices of recruitment, selection, staffing, training, promotion, rewards and incentives. KSAOs are resources to gain rents for the firm (Wright and Ulrich 2017). To gaining and maintaining the competitive advantage of a firm and a unit (Tang et al. 2015), CE is taken as a type (Schmelter et al. 2010) that it arises in situations of both resource heterogeneity and immobility in a firm and a unit. SHRM such as HPWS can add value for the firm and the unit by demanding heterogeneous labor with different types of skills and by supplying heterogeneous labor with different levels of skills (Wright and McMahan 1992). HPWS will deliver organizational information about goals, incentives and visions (Ostroff and Bowen 2016). The core focus of RBV in a firm and its units is 'novel compositions' (Schumpeter 1934), or 'heterogeneous resources integrate together to endow a new value by developing novel products or services' such as CE (Shane and Venkararaman 2000: 220). The underlying assumption of CE is the propensity to search for and combine the capabilities of new knowledge production and integration with current resources and information (Hayton 2005). CE is a contingent learning capability to continuously search new entrepreneurial opportunities and utilize current inequivalence of the market or information (Floyd and Wooldridge 1999; Hayton 2005; Mallén et al. 2016). For instance, the members could raise innovation, venturing and strategic renewal through a firm support resource sharing (Tang et al. 2015). Shin and Konrad (2017) also argue that HPWS is an effective cohesive system to cultivate innovation. A top-down firm-level HPWS approach indicates that a firm's factors influence outcomes by affecting the shared perceptions or behaviors in the units (Liao and Chuang 2004; Wright and Ulrich 2017). By adopting such 
top-down method, SHRM scholars neglect possible variances among the unit analysis of members from both the conceptual framework (Lepak and Snell 2002) and empirical evidence (Jiang et al. 2017; Liao et al. 2009; Nishii and Wright 2008; Wright and Ulrich 2017). Liao et al. (2009) also assert that diverse members in the different units of a firm would have inconsistent perceptions of HPWS. In sum, the link between HPWS and Corporate Entrepreneurship should consider the differences through individuals (Wright and Ulrich, 2017) such as manager-employee (i.e., dyad level) and unit level.

Following RBV, we argue that innovation, venturing, and strategic renewal in a unit needs to be driven by resources including training, information sharing, interdepartmental service, teams and participation, service discretion, performance appraisals, pay, and job design for quality work (Liao et al. 2009). Hayton (2005) and Schmelter et al. (2010) indicated that HPWS is an essential factor to promote CE in that HPWS can be utilized to select individuals with a relevant set of knowledge, skills and abilities to promote CE. Schuler (1986) suggested that a system of management that applies HPWS tends to induce changes that promote CE among the employees. The HPWS literature also indicates that certain antecedents in an organization, such as teamwork skills can enhance CE (Kaya 2006), yet, fails to address the relationship between firm-level HPWS and unit-level innovation. Following the call from previous research (e.g. Lepak et al. 2003; Marvel et al. 2016; Patel et al. 2013), this study examined whether the adoption of firm-level HPWS can promote CE at the lower levels of firms. Previous studies (e.g. Chuang et al. 2016; Mustafa et al. 2016; Zhou et al. 2019) indicate that HPWS stimulates innovation by inspiring and encouraging members' knowledge acquisition and exploitation (Liu et al. 2017). And appropriate 
HR activities such as training, rewards and incentives can encourage members to utilize their knowledge to pursue innovation (Kesting et al. 2016; Zhou et al. 2019).

By attracting, retaining and motivating human resources to form a match between the KSAOs of the organizational members and the entrepreneurial activities required by the job (Kaya 2006), HPWS of a firm can foster innovation, corporate venturing and strategic renewal activities of the units. A firmlevel HPWS provides 'a situational message for top management teams (TMTs) to shape their ideas and cognitions of the work system' (Liao et al. 2009: 375). Previous research (e.g. Delery and Doty 1996; Lepak and Snell 1999) indicated that KSAOs of a person were promoted by the macro-level HPWS. According to RBV, both firm and unit resource heterogeneity refer to the resources of a firm and a unit (i.e. human capital and bridging ties) and how different these resources across firms and units (Dyer and Singh 1998; Lane and Lubatkin 1998; Wright and McMahan 1992). Zhou et al. (2019) argue that the involvement of organizational members is based on organizational resources such as human capital. We contend that HPWS would create value by adopting to gain and produce the required human capital of members for the organization (e.g. Becker and Huselid 1998; Lado and Wilson 1994).

Past research (e.g. Liao et al. 2009; Simsek and Heavey 2011) used a single source to measure employees' human capital: a rating by the TMTs (e.g. Subramaniam and Youndt 2005), direct supervisors (Liao et al. 2009). Some researchers (e.g. Crocker and Eckardt 2014; Nyberg et al. 2014) suggest that unit-level human capital and individual-level human capital while similar are in fact different constructs: while unit-level human capital is a collective construct, aggregated from individuals, the 
individual-level human capital is a personal difference construct. Prior research of unit-level human capital seems merely considers that the KSAOs of employees in the unit (Chang 2015). However, managers in the unit should be considered as an asset of the unit. The unit-level human capital is defined as the employees' (managers and ordinary employees) collective KSA (Nyberg et al. 2014). If unit-level human capital is rated by a single source, it ignores opinions from other relevant sources. Following previous studies (e.g. Lane and Lubatkin, 1998; Liao et al. 2009), we make over the perceptions of unitlevel human capital from the 'manager-employee' pairing (the dyad). Simply put, we argue that the value of dyad-level human capital to increase from another dyad-level human capital is conjointly determined by the relative features of the employee dyad-level and the manager dyad-level (Lane and Lubatkin, 1998). Echoing previous studies (e.g. Cohen and Levinthal, 1989; Lane and Lubatkin, 1998), the dyadlevel human capital is a higher-level than unit-level because such dyad-level human capital can result in more entrepreneurial outcomes than simply unit-level human capital. In addition, firms use various HR functions to manage the related human resources and fit members' positions and strengthen their abilities (Lepak and Snell 2002). A firm implements HPWS, these members are possibly to solve job-related problems and produce new solutions by enhancing KSAOs (Zhou et al. 2019). Thus, we suggest that human capital is a dyad-level construct. These KSAOs of members (i.e. managers and employees) in the unit - i.e. dyad-level human capital - are among the resources of the unit very hard to copy (Armstrong and Shimizu 2007; Barney 1991). Thus, we expect that,

Hypothesis 1 A firm-level HPWS is positively associated to human capital at the dyad level. 


\subsection{Firm-level HPWS, dyad-level human capital, and unit-level CE}

RBV has two basic assumptions: resource heterogeneity and resource immobility (Barney 1991).

Thus, we argue that the natures of dyad-level human capital include resource heterogeneity and immobility, these resources of every unit are different and difficult to transfer. Moreover, units need to follow unit goals to conduct unit tasks, and as such are more possible to seek the specific behaviors at the required periods (Crocker and Eckardt 2014). Appropriate managed employees' human capital at the unit level can be the key drivers of promoting CE (Bornay-Barrachina et al. 2012; Sáa-Pérez and GarciaFalcón 2002; Wright et al. 2001). Usually, CE relies on the individual employees' knowledge, skills and abilities to undertake innovative activities, business venturing, and strategic renewal actions and thus human capital of the individual employees is vital to foster CE at the unit level. Since units try to pursue CE, employees engage in all efforts to use their KSAOs ( $\mathrm{Li}$ et al. 2018). To stimulate units' CE, members of units will have clearly strived for strategic renewals, innovation and venturing ( $\mathrm{Li}$ et al. 2018). We argue that collective KSAOs will promote unit's CE. The past research (e.g. Bornay-Barrachina et al. 2012) already revealed. Therefore, we argue that dyad-level human capital would fit unit needs to improve unit-level CE.

Studies (e.g. Liao and Chuang, 2004; Liao et al. 2009; Wright and Ulrich, 2017) assert related process variables would have top-down effects on unit's outcomes through an intermediate link of shared perceptions or behaviors in the units. SHRM scholars have adopted human capital as a theoretical base (Jackson and Schuler, 1995) to assert that an important role of HRM is its "buying" and "making" of 
organization-needed members' knowledge, skills and abilities, and promote positive outcomes (e.g. Becker and Huselid 1998; Lado and Wilson 1994; Liao et al. 2009). Based on an RBV perspective, we propose that unit-level CE was driven by a firm-level HPWS and then the dyad-level human capital. SHRM research suggests that HRM can facilitate the acquisition and development of employees' KSAOs required for the creation of visions for the organization (e.g. Becker and Huselid 1998). Researchers also argue that CE may be driven by human capital (e.g. Bashshur and Oc 2015). Thus, we contend that human capital may act as an intermediate link between HPWS and CE. Scholars (e.g. Donate et al. 2016; Fu et al. 2017) reveal that human capital mediates the positive relationship between HPWS and innovation at the firm-level by using the RBV. Equally, the individual employees need to become more entrepreneurial as a result of the investment from the firm-level HPWS. Individual employees' KSAOs and adaptation in undertaking innovation, business venturing and strategic renewal activities are improved by the firm-level HPWS (Marvel et al. 2016). Crocker and Eckardt (2014) also contend that units generate integrated employees' wisdoms to benefit unit-level outputs. Thus, the HPWS of a firm can benefit to recruit and train talents. For example, information sharing would help individual members to gain and absorb novel and comprehensive knowledge (Brown and Duguid 1991) and covering multiple knowledge areas that can be relevant to both corporate venturing and self-renewal activities (Marvel et al. 2016). Firms also assist selection practices to identify individual candidates who demonstrate entrepreneurial abilities such as proactiveness regarding CE. This can help employees to respond effectively to unexpected entrepreneurial opportunities or changes (Kaya 2006). Firms can use training 
to develop individual employees' entrepreneurial abilities and to improve their current job-related skills

(Amabile 1988) regarding CE at the unit level. Training and development can foster the employees' entrepreneurial behavior if they are relevant to the specific job environment and if they provide support for the employees' involvement (Schuler 1986) regarding CE. Also, training that supports creativity will reinforce innovativeness and potentially reinforce self-renewal and acceptance of new business expansion (Schmelter et al. 2010). Li et al. (2018) also indicate that the HPWS of a firm can motivate their human capital to facilitate knowledge creation. The strategic importance of innovation emophasized by a firm may facilitate collective efforts such as engaging in new product/service innovation by providing a beneficial context for knowledge creation ( $\mathrm{Li}$ et al. 2018). In particular, a firm with innovation-oriented values are more likely to learn, encourage various thinking and knowledge exchange (Li et al. 2018). Therefore, employees have the confidence to criticize current routines, challenge different ideas, and express their new solutions ( $\mathrm{Li}$ et al. 2018). As mentioned above, the HPWS of a firm benefits CE that largely depends on the nature of human capital resources by integrating collective knowledge. In summary, firm-level HPWS can boost a member's human capital through promoting them to develop entrepreneurial thinking and to react quickly to new opportunities and unexpected changes regarding CE. Firm-level HPWS is more possible to enhance the members' KSAOs in the unit, we argue that a dyad-level human capital will mediate the effect of the firm-level HPWS on CE at the unit level.

Hypothesis 2 The dyad-level human capital mediates the effect between the firm-level HPWS and the unit-level CE. 


\subsection{Firm-level HPWS and unit-level CE: Moderating influence of firm-level bridging ties}

It has been proposed above that a firm-level HPWS promotes a dyad-level human capital and influences the unit-level CE. Consequently, the dyad-level human capital mediates the effect of the firm-level HPWS and the unit-level CE. Increasingly research explores the relationship between HPWS and CE; however, the conditional boundaries for their relationship has not been neglected (Seeck and Diehl 2017).

Previous research (e.g. Chuang et al. 2016; Liao and Chuang 2004) assert that contextual factors play an essential element to moderate a top-down effect of higher-level HR practices on lower-level outcomes. Donate et al. (2016) emphasize that external social capital (i.e. bridging ties) plays an important role in the research of a firm's HPWS. We argue that external social capital is a boundary condition rather than a procedure. This is because external social capital serves a context for members to interact with external members such as managers at other firms or governmental officials. In addition, prior studies (e.g. Nyberg et al. 2014; Payne et al. 2011) already emphasize that future researchers should focus on which role a firm's external social capital (i.e. bridging ties) acts at the relationship between employees' human capital and subsequent outcomes at the unit level. Little research examined the effect such as a mediating influence of the dyad-level human capital can be reinforced or constrained by the bridging ties within which the unit-level employees operate.

According to RBV, the bridging ties are tangible resources (Wernerfelt 1984) that can create a situational resource for the recognition of new opportunities and self-renewal activities at the unit level. Wright and McMahan (1992) also proposed that social relationships such as bridging ties can a type of 
inimitability of competitive advantages deriving from creating a situational context to generate value such as CE. Such value creation (e.g. CE) only occur under unique bridging ties condition by using specific rules to allocate resources within the firm (Kuratko et al. 1990). Consequently, such value created under the context of the bridging tie adopting by human beings cannot be duplicated. The RBV perspective sees bridging ties as an important social resource linking the firm-level HR practices and the outcomes across levels as in the unit's CE (McEvily and Zaheer 1999; Gedajlovic et al. 2013). Therefore, we suggest that firm-level bridging ties are best considered as an asset, which can be taken as a moderator (Simsek and Heavey 2011). Ostroff and Bowen (2016) also indicate that researchers should examine the top-down effect of HPWS and bridging ties and how and why they influence employee responses. Therefore, we focus on bridging ties at the firm-level rather than unit-level in relation to how and why such ties moderates the relationship between firm-level HPWS and unit-level CE through dyad-level human capital. In addition, we contend that past studies neglect social capital as a boundary condition between HPWS and outcomes. In particular, a firm with external social capital (i.e. bridging ties) could be a situational enhancer rather than a processor between HPWS and outcomes. Therefore, we argue that cross-level (i.e. a top-down) effect of firm-level HPWS on unit-level CE should be examined.

Firm-level bridging ties by faciliating a interpersonal interaction and knowledge exchange promotes innovation, which can be seen as a moderator (Stam and Elfring 2008). Strong firm-level bridging ties may be taken as a contextual factor (Howell et al. 1986) and more enhance the positive relationship of firm-level HPWS on unit-level CE by an indirect influence on a dyad-level human capital. The firm- 
level bridging ties increases the relationship of the firm-level HPWS on unit-level CE by the dyad-level human capital. How might the work? First, firm-level bridging ties offers a specific context of firms in which a firm-level HPWS can raise the member's perception of innovativeness and entrepreneurial ideas in terms of CE through upgrading the dyad-level human capital in the workplace. Managers may acquire various useful resources and experiences to deal with a challenging external environment (Stuart et al. 1999) through connecting bridging ties to other firms and government officials (Stam and Elfring 2008). Su et al. (2018) indicate that an organization facilitating HPWS not only increase the members' human capital but also better promote bridging ties. Therefore, we contend that when an employee is located in a firm-wide situation that is formed by a high level of external networking, the employee is likely to respond rapidly to various entrepreneurial possibilities for start-up activities (Gaglio and Katz 2001), because what is emphasized on the firm-level HPWS collaborated with the firm's bridging ties. The collective employees at the dyad-level are accordingly more willing to raise their KSAOs as required by the firm's HPWS and therefore be more prepared to involve in the creation of a firm's bridging ties (Burt 1992) that would contribute to new business development and strategic renewal activities. The result is that a firm with high-quality social relationships is viewed as constantly accessible. Accordingly, connected external relationships are boosted, creating a positive environment in which more members will recognize the new opportunities opened up by $\mathrm{CE}$ at the unit level. Second, if that strong external connected networks do not exist at the firm level, the members would less have stimulated from external environment, as the situation cultivated in that firm by the HPWS may give increase to cognitive 
dissonance among the firm's managers. Therefore, the promotion of innovation, new business opportunities and self-renewal activity within the firm would be muted, and this may negatively influence the $\mathrm{CE}$ at the unit level. Finally, the dyad-level human capital can foster the pursuit of new venturing opportunities, innovation, and self-renewal by creating beneficial bridging ties in the firm. We suggest that an external interaction of firm and connected networks, which accelerates an inter-unit flow of information and knowledge, will complement the intra-unit information exchange by increasing the employees' ability to recognize opportunities at the unit level. Also, under conditions of strong external connection, the total amount of knowledge sharing will be increased including sharing highly sensitive or confidential knowledge (Yli-Renko et al. 2001). This is because there is less risk that employees at the unit level would opportunistically exploit such knowledge (McEvily et al. 2003). Moreover, the discovery for novel business opportunities and the exploitation of strategic renewal activity are by nature a social activity (Sullivan and Marvel 2011). Consequently, novel business development and self-renewal activities are influenced by the external social context in the firm (Mosey and Wright 2007).

We contend that firm-level bridging ties could reinforce the mediation influence of dyad-level human capital between firm-level HPWS and unit-level CE. This is because firm-level bridging ties can assist managers and employees to develop higher level of interactions externally such as governmental officials to acquire knowledge and information. In addition, a firm consisting of high levels of bridging ties provides more resource bases (i.e. dyad-level human capital) to maintain competitive advantages (Adler and Kwon 2002; Floyd and Wooldridge 1999). Members of a firm promote CE through 
knowledge exchange with the external social networks of the firm (Li et al. 2018; Shipilov et al. 2017).

These members of a firm would understand the demands of managers at other firms and government officials, and adapt behavioral and communication patterns accordingly to fit the social situation in the context of HPWS (Li et al. 2018). Following the RBV perspective (McEvily and Zaheer 1999), the firmlevel bridging ties create a situational context to augment the positive relationship of a firm-level HPWS on unit-level CE by the dyad-level human capital. We hypothesize,

Hypothesis 3 Firm-level bridging ties positively moderates the indirect influence of a firm-level HPWS and a unit-level CE, via the dyad-level human capital, so that the indirect influence is stronger when the firm-level bridging ties is stronger.

\section{Method}

\subsection{Research samples and design}

We focus on CE in the Taiwanese context because innovation has been strongly emphasized as a driver of economic growth and industrial development by the Taiwanese government. Since 2016, the Taiwanese government has promoted promoting the "Key Innovative Industries", including manufacturing and service sectors (Ministry of Economic Affairs [MOEA] 2016: 8). Therefore, in early 2016, chief executive officers (CEOs) of 138 manufacturing and service sectors firms in Taiwan were invited to participate. Before the formal tests of our research, we followed Hinkin (1998) practices to conduct a pre-test performed for validation of exploratory factor analysis (EFA). The samples of EFA are above 150, and item: samples are equal to from 1:4 to 1:10 (Hinkin 1998: 111). We acquired 291 
valid samples for the pre-test. The results of EFA show well validations of variables (please see the Appendix).

Multisource, different time points and multilevel data were collected to reduce CMB (Podsakoff et al. 2003). In 2016, firm-level HPWS were assessed by senior managers of firm's headquarters (HQs). In 2017, dyad-level human capital was assessed by unit managers and employees; firm-level bridging ties were assessed by senior managers of firm's headquarters (HQs). In 2018, unit-level CE was assessed by unit managers. Finally, in total 534 senior managers from the HQs of the firms, 1602 managers and 3956 employees from 247 units in 108 firms answered the surveys. Where we had fewer than two managers from each unit, fewer than two employ from each unit, and fewer than two senior managers from the HQs these were excluded from our final sample. We received usable surveys from 420 senior managers (78.7\%), 1260 managers (78.7\%) and 3348 employees (84.6\%) of 210 units from 96 firms. On average each firm had 2.19 units (s.d. $=0.17)$ and 4.38 senior managers $($ s.d. $=0.23)$; a unit had 6.00 managers $($ s.d. $=0.00)$ and 15.94 employees $($ s.d. $=2.76)$. No significant differences were discovered between valid and excluded in our sample in terms of firm size or number of the unit. According to Armstrong and Overton (1977), evaluating non-response bias by comparing first 10 percent and last 10 percent respondents. We did not discover significant differences across these dimensions. These samples included 84 manufacturing sector firms $(87.5 \%)$ and 12 service sector firms $(12.5 \%)$. The unit-level managers' average tenure is 9.14 years (Table 3), and their average age is 49.13 (s.d. $=0.90)$. 
In addition, we employed a Harman one-factor analysis to test the CMB by conducting an unrotated factor analysis. In senior manager sample: Eight factors were acquired (so more than one factor); the variance explained by the first factor was $18.44 \%$ (so less than $50 \%$ ); and finally, the variance explained by the first factor was less than half of the total variance explained $(73.75 \%)$. In unit manager sample: Four factors were acquired (so more than one factor); the variance explained by the first factor was $30.09 \%$ (so less than $50 \%$ ); and finally, the variance explained by the first factor was less than half of the total variance explained $(71.31 \%)$. Finally, our result showed that social desirability was not associated with these variables $(\mathrm{p} \geq .05)$ and no discovery significant differences between the two models (Podsakoff et al. 2003). In sum, we can suggest that CMB does not emerge to show in the data.

\subsection{Measurements}

To confirm reliability and validity of scales in questionnaires, we adopted the back-translation method (Brislin 1980). The appendix provides the question from the questionnaire.

\subsubsection{Unit-level corporate entrepreneurship}

To measure unit-level corporate entrepreneurship, we adapted measures from previous studies (Simsek 2007; Zahra 1996) with a 17-item 7-point scale. Scale reliability $(\alpha=0.75)$. The scale reveals a good model fit $\left[\chi^{2}=7.93, d f=2, p<0.05\right.$, root mean square error of approximation $(\mathrm{RMSEA})=0.05$, comparative fit index $(\mathrm{CFI})=0.99$, goodness-of-fit index $(\mathrm{GFI})=0.99$, Tucker-Lewis index $(\mathrm{TLI})=$ 0.99]. Tests show that managers from the same unit had high agreement regarding unit-level CE [mean 
$\left.\mathrm{r}_{\mathrm{wg}(\mathrm{j})}=0.95, \operatorname{ICC}(1)=0.40, \operatorname{ICC}(2)=0.80\right]$ with a good reliability $(\alpha=0.94$, Composite reliability $(\mathrm{CR})$

$=0.88$, average variance extracted $(\mathrm{AVE})=0.64)$.

\subsubsection{Firm-level HPWS}

To measure firm-level HPWS, we adapted from Liao et al. (2009) with a 37-item 7-point scale. Scale reliability $(\alpha=0.95)$. The scale reveals a good model fit $\left[\chi^{2}=6.06, d f=2, p<0.05\right.$, RMSEA $=0.07$, CFI $=0.99, \mathrm{GFI}=0.99, \mathrm{TLI}=0.99]$. The tests show that senior managers from the same firm had high agreement regarding the firm-level HPWS $\left[\right.$ mean $\left.r_{w g(j)}=0.98, \operatorname{ICC}(1)=0.46, \operatorname{ICC}(2)=0.79\right]$ with a good reliability $(\alpha=0.96, \mathrm{CR}=0.92, \mathrm{AVE}=0.75)$.

\subsubsection{Firm-level bridging ties}

To measure firm-level bridging ties, we adapted from Peng and Luo (2000) with a 6-item 7-point scale.

The scale reveals a good model fit $\left[\chi^{2}=3.05, d f=2, p>0.01, \mathrm{RMSEA}=0.04, \mathrm{CFI}=0.99, \mathrm{GFI}=0.99\right.$, $\mathrm{TLI}=0.99]$. The tests show that senior managers from the same firm had high agreement regarding the firm-level bridging ties $\left[\right.$ mean $r_{\mathrm{wg}(\mathrm{j})}=0.88, \operatorname{ICC}(1)=0.39, \operatorname{ICC}(2)=0.74$ ] with a good reliability $(\alpha=$ $0.88, \mathrm{CR}=0.90, \mathrm{AVE}=0.70)$

\subsubsection{Dyad-level human capital}

To measure dyad-level human capital, we adapted from Subramaniam and Youndt (2005) with a 5-item 7-point scale. The scale reveals a good model fit (managers: $\left[\chi^{2}=7.40, d f=2, p<0.05, \operatorname{RMSEA}=0.05\right.$, $\mathrm{CFI}=0.99, \mathrm{GFI}=0.99, \mathrm{TLI}=0.99]$; employees: $\left[\chi^{2}=59.27, d f=2, p<0.01, \mathrm{RMSEA}=0.08, \mathrm{CFI}=\right.$ $0.99, \mathrm{GFI}=0.99, \mathrm{TLI}=0.98])$. The tests show that managers and employees from the same unit had high 
agreement regarding the dyad-level human capital (managers: $\left[\right.$ mean $\mathrm{r}_{\mathrm{wg}(\mathrm{j})}=0.85, \operatorname{ICC}(1)=0.46, \operatorname{ICC}(2)$

$=0.83]$; employees: $[$ mean rwg $=0.85, \operatorname{ICC}(1)=0.39, \operatorname{ICC}(2)=0.91])$ with a good reliability (managers:

$\alpha=0.94, \mathrm{CR}=0.94, \mathrm{AVE}=0.80 ;$ employees: $\alpha=0.91, \mathrm{CR}=0.92, \mathrm{AVE}=0.74)$.

\subsubsection{Covariates}

First, size effect (number of employees in a firm, subordinates under a manager, top management team

(TMT) in a firm), environmental uncertainty and industry sectors (manufacturing and service industries)

were controlled because these are connected to a firm's ability about responding dramatic and complex

resource contexts variation (Kuratko et al. 1997). Second, firm age and unit age were controlled because

these variables are taken as being associated with unit-level CE (Hayton 2005). Third, unit-level managers' tenure was controlled because the variable is taken as being associated with unit-level CE

(Simsek 2007).

These measurements were four distinct dimensions rather than one single dimension to examine

construct-related discriminant validity (i.e. firm-level high-performance work systems; firm-level bridging ties; dyad-level human capital; unit-level corporate entrepreneurship) (Anderson and Gerbing 1988; Bagozzi et al. 1991). The four-factor hypothesized model was compared to 11 competitive models.

Table 1 presents the results of model comparison. Comparison to the other models, the hypothesized model has the best model fit.

We adopted Mplus 7.4 (Muthén and Muthén 2015) to conduct comparison of structural models (including reverse causality models) and Monte Carlo simulation to robustly examine the confidence 
intervals (CIs) of all paths, mediation effects (James et al. 2006) and moderated mediation effects in the multilevel moderated mediation (Bauer et al. 2006; Hayes and Rockwood 2017; Hayes et al. 2017). Table 2 shows comparison of structural models.

[Tables 1 and Table 2 here]

\section{Results}

To investigate the nomological validity of these measures, we followed Spiro and Weitz's (1990) approach to test the correlations between firm-level HPWS, unit-level CE, and dyad-level human capital (Table 3). The results reveal that these scales have good nomological validity. Table 3 also depicts descriptive statistics and correlations. We test these hypotheses by utilizing hierarchical linear modelling (HLM) because of the nature of nested data.

We adopt grand mean-centered to interpret for the HLM results to control the Level 1 effects for examining the incremental effects of the Level 2 variables and decreases multicollinearity in Level 2 estimates (Hofmann and Gavin 1998). Following Kenny et al. (1998) we used three steps to test mediation effect. First, there was a significantly positive influence of firm-level HPWS and dyad-level human capital $(\gamma=0.88, p<0.01$, Model 1, Table 4). Hypotheses 1 was supported. Second, there was a significantly positive influence of firm-level HPWS and unit-level CE $(\gamma=0.87, p<0.01$, Model 2, Table 4). Third, dyad-level human capital mediated the influence of firm-level HPWS and unit-level CE ( $\gamma=$ $0.49, p<0.01$, Model 3, Table 4), and the influence of firm-level HPWS remained significant but reduced $(\gamma=0.44, p<0.05$, Model 3, Table 4). Hypotheses 2 was supported. 
In Model 4, we regressed the slope estimates for unit-level CE acquired from Level 1 on bridging ties at Level 2 to test this moderated effect (Bryk and Raudenbush 1992). Additionally, since false crosslevel moderated effect might be found if between-groups moderated effects are not controlled for (Hofmann and Gavin 1998), we included the moderated effects of firm-level HPWS $\times$ firm-level bridging ties at Level 2. The moderated effect of firm-level HPWS and firm-level bridging ties was not significant $(\gamma=-0.07, p>0.10$, Model 4, Table 4), however, the cross-level moderated effect was significant $(\gamma=$ $0.10, p<0.05$, Model 4, Table 4). These results provide support for Hypothesis 3 and indicate that a positive firm-level bridging ties increased the effect of firm-level HPWS on unit-level CE through dyadlevel human capital.

[Tables 3 and Table 4 here]

Finally, we also conducted simple slope tests. The indirect influence of firm-level HPWS (via dyadlevel human capital) on unit-level CE at low and high levels of firm-level bridging ties $(t=5.83, p<$ $0.01)$

[Fig. 2 here]

\subsection{Robustness check}

We used Mplus 7.4 (Muthén and Muthén 2015) including bootstrapping technique to run the analyses.

Table 5 showed that firm-level HPWS was positively associated to dyad-level human capital $(b=0.99$, $p<.001 ; 95 \% \mathrm{CI}=[0.90,1.08])$. Therefore, hypothesis 1 was supported. Second, firm-level HPWS was positively associated to unit-level $\mathrm{CE}(b=0.71, p<.05 ; 95 \% \mathrm{CI}=[0.24,1.18])$. Third, dyad-level human 
capital was positively related to unit-level $\mathrm{CE}(b=0.69, p<.001 ; 95 \% \mathrm{CI}=[0.48,0.90])$. Fourth, dyadlevel human capital positively mediated the effect of firm-level HPWS and unit-level CE $(b=0.68, p$ $<.001 ; 95 \% \mathrm{CI}=[0.48,0.88])$. Thus, hypothesis 2 was supported again. Fifth, the cross-level moderated effect of dyad-level human capital and firm-level bridging ties positively moderated on unit-level CE ( $b$ $=0.11, p<.01 ; 95 \% \mathrm{CI}=[0.04,0.18])$. Finally, firm-level bridging ties positively moderated the influence of firm-level HPWS and unit-level CE by dyad-level human capital $(b=0.11, p<.01 ; 95 \% \mathrm{CI}$ $=[0.05,0.17])$. Following Wiedemann et al.'s (2009) approach to robustly check the moderated mediation effects by a simple slope test, Fig. 3 the indirect influence is plotted at all values of the moderator with a 95\%-confidence band. Table 5 and Fig. 3 revealed that the conditional indirect influence of firm-level bridging ties between firm-level HPWS and unit-level CE by dyad-level human capital was significant positive difference between higher $(b=0.89, p<.001 ; 95 \% \mathrm{CI}=[0.27,1.51])$ than low one standard deviation of mean $(b=0.34, p>.05 ; 95 \% \mathrm{CI}=[-0.28,0.96])$. Therefore, hypothesis 3 was also supported.

[Table 5 and Fig. 3 here]

Following previous studies (e.g. Baum et al. 2003) we use Stata14 to perform the tests treating firmlevel HPWS as endogenous and the remaining variables as instruments for firm-level HPWS. Therefore, the null and alternative hypotheses are: (1) Null Hypothesis: Firm-level HPWS is exogenous; (2) Alternative Hypothesis: Firm-level HPWS is endogenous. Table 6 presents the findings of the tests. Both findings do not reject the null hypothesis that firm-level HPWS is exogenous at the high significance 
level of $1 \%$.

[Table 6 here]

Following previous studies (e.g. Baum et al. 2003), we use Stata14 to perform the tests treating firm-level bridging ties as endogenous and the remaining variables as instruments for firm-level bridging ties. Therefore, the null and alternative hypotheses are: (1) Null Hypothesis: Firm-level bridging ties is exogenous; (2) Alternative Hypothesis: Firm-level bridging ties is endogenous. The results of the tests are in Table 7. Both test results do not reject the null hypothesis that firm-level bridging ties is exogenous at the high significance level of $1 \%$.

[Table 7 here]

\section{Discussion}

Previous research has explored how SHRM practices affect organizational members and organizations (e.g. Bornay-Barrachina et al. 2012; Gong et al. 2010; Guthrie 2001; Wei and Lau 2008). Their finding indicated that an organization's performance was driven by a strategy-aligned HRM. We echo many scholars' calls to explore related black boxes between SHRM and CE across levels (e.g. Hayton 2005; Schmelter et al. 2010; Wright and Ulrich 2017), our study concentrates on the growth of CE, SHRM practices, and the procedures underlying their connection. In particular, we demonstrated that a firmlevel HPWS was positively associated to unit-level CE. Dyad-level human capital mediated the influence of firm-level HPWS and unit-level CE. In addition, the firm-level bridging ties acted as a moderating role: when the firm-level bridging ties was stronger, the indirect positive relationship with unit-level CE 
was stronger for firm-level HPWS. Overall, several theoretical and practical contribution are apparent.

By responding to the call by Fu et al. (2017), we conducted multilevel method with a focus on how multiple internal and external interaction effects of a firm's HPWS influences units' practices .Our findings echo Li et al.'s (2018) arguments, and we reveal that a firm can facilitate the emergence of human resources within units through external collective interactions of a firm, furthering our understanding about the microfoundations of the RBV.

\subsection{Theoretical implications}

This study departs from the common approach of studying $\mathrm{CE}$ at a single level and examines the relationship among a firm-level HPWS, dyad-level human capital, firm-level bridging ties, and unit-level CE. Overall, this study extends RBV perspective to include the unit- and cross-level relationships with

CE. In an important departure from prior studies (e.g. Hayton 2005), which found mixed results on the influence of the firm-level HPWS and CE at the organizational level, this study shows that the firm-level HPWS has a positive effect on the unit-level CE. While much emphasis has been placed on the strong influence of CE on firm performance (e.g. Davidsson and Wiklund 2001; Zahra 1996), this study finds a bundle of HPWS that have a strong effect of CE at lower levels such as the unit level. Our research supports Kaufman's (2015b) arguments by employing RBV. HPWS is a directional system and then the system will cause outcomes. Our results contradict the propositions by scholars of scarce resources and adaptability perspective, that is, the causal relationship between HPWS and performance may be reversed. In line with RBV lens, firm-level HPWS can act as an antecedent of organizational outcomes, such as 
$\mathrm{CE}$ at the lower levels of the organizational bureaucracy. Moreover, advancing the existing SHRM research, this study complements to our comprehension of the effect of HPWS on unit level outcomes by centering on an important but under-studied indicator (Hayton 2005; Huselid 1995; Kaya 2006; Nyberg et al. 2014). Following RBV, this study posits that the dyad-level human capital is associated to the firm-level HPWS and unit-level CE. Given the novelty of the firm-level HPWS approach to unitlevel CE, no prior research has theorized and empirically examined any potential explanatory mechanism for it. In particular, this study finds that the firm-level HPWS has a positive indirect relationship with unit-level CE via the dyad-level human capital. The demonstration of this indirect effect is important, because the firm-level HPWS could risk being lost into obscurity if scholars simply focus on the insignificant and direct results regarding CE (Hayton 2005). Moreover, the exploration of the indirect role of the dyad-level human capital echoes the prior call for studies to the mediating mechanism of human capital (e.g. Schmelter et al. 2010). This study hence offers a more complete view of the role of the firm-level HPWS on unit-level CE. The valuable of dyad-level human capital supports the RBV notion in that firms can use HPWS to train employees' KSAOs to utilize the achievement of the firm's strategic goals (Boxall 1996; Day 1994). Echoing Armstrong and Shimizu’s (2007) and Barney’s (1991) arguments to demonstrate that KSAOs of all members in the units rather than only managers or employees who represent in the units are very hard to imitate as important assets. This implies that members can be fully motivated and exploited by utilizing a firm's HPWS to cultivate unit-level CE (e.g. Schmelter et al. 2010; Zhang and Jia 2010). Our results demonstrate this assumption and such findings 
contribute to CE by exploring its antecedent and indirect effect from RBV.

Moreover, drawing from RBV, we have found that the indirect influence of the firm-level HPWS and unit-level CE varies as a function of the bridging ties at the firm level. Prior researchers found that there were mixed results for HPWS and CE at a single level. This study therefore advances the SHRM approach to CE (e.g. Hayton 2005) by identifying the bridging ties at the firm level as a novel contextual factor. This implication is that the influence of the firm-level bridging ties may be exerted in different manners, depending on the maintenance and expansion of the accumulated social relationships to promote the seek new ventures, innovation and strategic renewal activities. In other words, too much attachment of the bridging ties can lead to a situation in which innovation and business venturing actions are stifled. In general, responding to the call for more research into the role of bridging ties (Gedajlovic et al. 2013; Nyberg et al. 2014; Payne et al. 2011), we demonstrate that the firm-level bridging ties may actually play a positive moderating role when firms utilize the HPWS to foster unit-level CE using the dyad-level human capital. It therefore offers a new insight into the boundary condition of the firm-level bridging ties in the $\mathrm{CE}$ literature. Importantly, this study provides novel contributions to the multilevel theory of CE (e.g. Covin and Slevin 1991; Hannah and Lester 2009; Hunt 1991). Multilevel theory of CE refers to the manner in which corporate entrepreneurship is manifested across organizational levels influences corporate entrepreneurship's ability to fulfill its promise as a driver of growth and renewal (e.g. Burgelman 1983, 1991). Multilevel theory of CE is needed because successful entrepreneurial corporations are those in which CE pervades the organization at all levels (Covin and Slevin 1991). 
Studies on CE also indicated that unit-level CE is vital to large diversified companies (Davidsson and

Wiklund 2001). CE scholars mostly concentrate on the roles of firm-level or organizational-level variables rather than the lower level of the organizational landscape such as the unit. One noteworthy finding of this study is the moderating influence of firm-level bridging ties on the effect of firm-level HPWS and unit-level CE via dyad-level human capital. This result is consistent with the notion that CE is a multilevel phenomenon that involves cross-level relationships (e.g, Burgelman 1983, 1991; Covin and Slevin 1991). It also extends the prior research (e.g. Carpenter et al. 2012; Gedajlovic et al. 2013; Lavie 2006) to show that the lack of bridging ties at the firm-level is a situational enhancer may cause the reluctance of employees at the unit level to advance innovation, novel venturing and self-renewal activities. This implies that firm-level CE does not equate to the average of dyad-level CE. Therefore, a multilevel theory of $\mathrm{CE}$ involves a conceptualization of unit-level $\mathrm{CE}$ advances the understanding of simply averaging of individual CE activities (Hitt et al. 2007). Our research resonances previous research (e.g. Nyberg et al.'s 2014; Payne et al.'s 2011) arguments using RBV through integrating human capital and social capital research from macro to micro, we reveal that firm-level bridging ties could be a contextual variable that moderates the relationship between firm-level HPWS and unit-level CE through dyad-level human capital.

\section{Practical implications}

Our study illustrates that SHRM plays a core element in facilitating CE. Li et al. (2018) also recommend that firms need to systematically promote the accumulation of human resources. For instance, we argue 
that leaders of a firm should design and structure a series of comprehensive HR systems including job design, compensation, information sharing, training and development practices to fit the goal for high performance of a firm. In particular, leaders of a firm could sort out job descriptions for different jobs to design corresponding job goals and then offer suitable salary and bonus, information sharing, training and relevant promotion. As $\mathrm{CE}$ activities are often carried out by units, understanding unit-level $\mathrm{CE}$ is of practical importance to managers. Our study also suggests that firm-level HPWS is an important antecedent for promoting unit-level CE. Firms can gain more value from SHRM through the unified implementation of HPWS and executives of a firm should retain unit talents. As our research reveals, human capital is the core of $\mathrm{CE}$ development and was established by all members of the unit over the years. If the most qualified and skilled people leave or switch units, HPWS for investment to develop human capital (i.e. selective staffing, training, high salary systems) will not be of much value (Donate et al. 2016). Moreover, talent loss leads to damage to unit human capital and the firm's bridging ties. When members of a firm establish external connections and networks with other managers at other firms or government officials for knowledge exchange, some of these intangible assets may also be threatened because of the talent loss. Therefore, loss of these talents may result in insufficient CE of a unit that may seriously damage the firm. It should be supported by the application of the HPWS throughout the firm. However, if firms attempt to pursuit on the competitive advantage of CE, it is not enough to focus only on the HRM system. Managers may also encourage their employees to be continually innovative, by exploiting the collective knowledge, skills and ability of unit employees. For striving innovative firms, 
we revealed that the importance of applying HPWS to inspire collective knowledge exchange interaction.

The implication is that managers need to consider how to use an appropriate firm-level HPWS to recruit and select employees with the professional KSAOs to meet the requirement of promoting business venturing activities. Managers can also consider adapting the firm-level HPWS, to include aspects such as job design, compensation, information sharing, training and development practices with a focus on innovation and ideas (von Bonsdorff et al. 2016). Moreover, managers can design programs to help employees learn how to implement innovative ideas and devote resources to promoting $\mathrm{CE}$ at the unit level. Furthermore, a firm-level HPWS can include such practices as higher rewards to encourage employees to develop entrepreneurial projects. Overall, firms need to create a social context and establish a knowledge exchange platform that supports their employees and uses their professional KSAOs to practice $\mathrm{CE}$ at the unit level. In addition, managers may also find bridging ties useful to promote unitlevel $\mathrm{CE}$, and this can be done through situational factors such as social interaction and interrelationships external to the firm. For instance, managers can assist the intrafirm promotion of innovation, business venturing and strategic renewal action by creating a close-knit network with intensive social interaction with external of the firm. In addition, a firm should enhance a firm's bridging ties to a unit's CE by establishing a site or a platform of knowledge sharing and transfer with external networks, including managers at other firms and government officials. For example, members of a firm would inventory lists of external networks and regularly connect with managers at other firms and government officials. In particular, according to our research results, when members of a firm interact with the outside based on 
the perspective of a firm' overall strategies, HPWS can better raise CE. Therefore, a firm should express clear strategic visions and recognize the potential value of innovation to let employees support a firm's goals and ensure that employees' collective efforts are moving in the right direction (Li et al. 2018).

\section{Limitations and future avenues}

Our study has limitations but does offer new directions for future research. First, the variable of $\mathrm{CE}$ has only three dimensions. Future research can replicate the research with a broader sampling size in different economies (e.g. Semrau et al.'s 2019 research) or industries (i.e. the software development industry (Bhatti and Ahsan 2016)). According to a call of Kraus et al. (2019), future researchers should develop a construct of digital entrepreneurship in the era of digital business models. Although we did check for any response bias, future replication studies could assist in reducing any potential response bias. For instance, other strategic orientations, such as a learning orientation and a market orientation can also be examined (Schmelter et al. 2010). Second, our study is one of the first to investigate dyad-level human capital as a process that links the firm-level HPWS and the unit-level CE. Other potential unit processes may be found to exist such as dyad-level absorptive capacity, because such a construct may provide more specific insights into the process of how new knowledge is acquired, transferred and exploited to promote CE. Third, our study does not test other dimensions of intellectual capital such as organizational capital that would interfere the multilevel influences of HPWS on CE at the unit level. It is likely that the different level organizational capital might have different influences on $\mathrm{CE}$ at the unit-level. Fourth, following Bouncken et al. (2020), Hock-Doepgen et al. (2020) and Kraus et al. (2018), future scholars 
could use fuzzy-set qualitative comparative analysis (fsQCA) to robustly check the empirical results.

Finally, we argue that future researchers should referent Ferreira et al.'s (2019) review paper and Palmer et al. (2019) to explore the antecedents and outcomes of CE by adopting different theories, including knowledge spillover theory of entrepreneurship, creation and networks theory, decision-making theory, specialization of labor, social entrepreneurship theory, entrepreneurship in the informal economy, and theory of planned behaviour.

\section{References}

Adler PS, Kwon S-W (2002) Social capital: Prospects for a new concept. Acad Manag Rev 27(1): $17-40$

Ahuja G (2000) Collaboration networks, structural holes, and innovation: A longitudinal study. Adm Sci Q 45(3): 425-455

Alvarez SA, Busenitz LW (2001) The entrepreneurship of resource-based theory. J Manag 27(6): $755-775$

Amabile TM (1988) A model of creativity and innovation in organizations. In: Staw BM and Cummings LL (eds.) Research in organizational behavior, Vol 10. JAI Press, Greenwich, CT, pp 123-167

Anderson JC, Gerbing DW (1988) Structural equation modeling in practice: A review and recommended two-step approach. Psychol Bull 103(3): 411-423

Armstrong CE, Shimizu K (2007) A review of approaches to empirical research on the resourcebased view of the firm. J Manag 33(6): 959-986 
Armstrong JS, Overton TS (1977) Estimating nonresponse bias in mail surveys. J Mark Res 14(3):

396-402

Bagozzi RP, Yi Y, Phillips LW (1991) Assessing construct validity in organizational research. Adm Sci Q 36(3): 421-458

Barney J (1991) Firm resources and sustained competitive advantage. J Manag 17(1): 99-120

Bashshur MR, Oc B (2015) When voice matters: A multilevel review of the impact of voice in organizations. J Manag 41(5): 1530-1554

Bauer DJ, Preacher KJ, Gil KM (2006) Conceptualizing and testing random indirect effects and moderated mediation in multilevel models: new procedures and recommendations. Psychol Methods 11(2): 142-163

Baum CF, Schaffer ME, Stillman S (2003) Instrumental variables and GMM: Estimation and testing. Stata J 3(1): 1-31

Becker BE, Huselid MA (1998) High performance work systems and firm performance: A synthesis of research and managerial implications. In: Ferris GR (ed.) Research in personnel and human resources management, Vol. 16. JAI Press, Greenwich, CT, pp 53-101

Becker GS (1964) Human capital: A theoretical and empirical analysis, with special reference to education. National Bureau of Economic Research, New York, NY

Bhatti MW, Ahsan A (2016) Global software development: an exploratory study of challenges of globalization, HRM practices and process improvement. Rev Manag Sci 10(4): 649-682 
Bornay-Barrachina M, De la Rosa-Navarro D, López-Cabrales A, Valle-Cabrera R (2012) Employment relationships and firm innovation: the double role of human capital. $\mathrm{Br} \mathrm{J}$ Manag 23(2): 223-240

Bouncken RB, Fredrich V, Kraus S (2020) Configurations of firm-level value capture in coopetition. Long Range Plann 53(1): 101869

Boxall P (1996) The strategic HRM debate and the resource-based view of the firm. Hum Resour Manag J 6(3): 59-75

Brislin RW (1980) Translation and content analysis of oral and written materials. In: Triandis HC and Berry JW (eds.) Handbook of cross-cultural psychology, Vol. 2. Allyn \& Bacon, Boston, MA, pp. 389-444

Brown JS, Duguid P (1991) Organizational learning and communities-of-practice: Toward a unified view of working, learning, and innovating. Organ Sci 2(1): 40-57

Bryk AS, Raudenbush SW (1992) Hierarchical linear models: Applications and data analysis methods. Sage, Newbury Park, CA

Burgelman RA (1983) A process model of internal corporate venturing in the diversified major firm. Adm Sci Q 28(2): 223-244

Burgelman RA (1991) Intraorganizational ecology of strategy making and organizational adaptation: Theory and field research. Organ Sci 2(3): 239-262

Burt R (1992) Structural holes: The social structure of competition. Cambridge, MA: Harvard 
University Press

Carpenter MA, Li M, Jiang H (2012) Social network research in organizational contexts. J Manag 38(4): 1328-1361

Chang Y-Y (2015) A multilevel examination of high-performance work systems and unit-level organisational ambidexterity. Hum Resour Manag J 25(1): 79-101

Chen S-Y, Uen JF, Chen C-C (2016) Implementing high performance HR practices in Asia: HR practice consistency, employee roles, and performance. Asia Pacific J Manag 33(4): 937-958

Chuang C-H, Jackson SE, Jiang Y (2016) Can knowledge-intensive teamwork be managed? Examining the roles of hrm systems, leadership, and tacit knowledge. J Manag 42(2): 524554

Cohen WM, Levinthal DA (1989) Innovation and learning: Two faces of R\&D. Econ J 99(397):569-596

Cooke FL (2018) Concepts, contexts, and mindsets: Putting human resource management research in perspectives. Hum Resour Manag J 28(1): 1-13

Covin JG, Slevin DP (1991) A conceptual model of entrepreneurship as firm behavior. Entrep Theory Pract 16(1): 7-25

Crocker A, Eckardt R (2014) A multilevel investigation of individual- and unit-level human capital complementarities. J Manag 40(2): 509-530

Davidsson P, Wiklund J (2001) Levels of analysis in entrepreneurship research: Current research 
practice and suggestions for the future. Entrep Theory Pract 25(4): 81-99

Day GS (1994) The capabilities of market-driven organizations. J Mark 58(4): 37-52

Delery JE, Doty DH (1996) Modes of theorizing in strategic human resource management: Tests of universalistic, contingency, and configurational performance predictions. Acad Manag J 39(4): $802-835$

Donate MJ, Peña I, Sánchez de Pablo JD (2016) HRM practices for human and social capital development: effects on innovation capabilities. Int J Hum Resour Manag 27(9): 928-953

Dyer JH, Singh H (1998) The relational view: Cooperative strategy and sources of interorganizational competitive advantage. Acad Manag Rev 23(4): 660-679

Ferreira JJM, Fernandes CI, Kraus S (2019) Entrepreneurship research: mapping intellectual structures and research trends. Rev Manag Sci 13(1): 181-205

Floyd SW, Wooldridge B (1999) Knowledge creation and social networks in corporate entrepreneurship: The renewal of organizational capability. Entrep Theory Pract 23(3): 123143

Fu N, Flood PC, Bosak J, Rousseau DM, Morris T, O'Regan P (2017) High-performance work systems in professional service firms: Examining the practices-resources-uses-performance linkage. Hum Resour Manag 56(2): 329-352

Gaglio CM, Katz JA (2001) The psychological basis of opportunity identification: Entrepreneurial alertness. Small Bus Econ 16(2): 95-111 
Gedajlovic E, Honig B, Moore CB, Payne GT, Wright M (2013) Social capital and entrepreneurship: A schema and research agenda. Entrep Theory Pract 37(3): 455-478

Geletkanycz MA, Hambrick DC (1997) The external ties of top executives: Implications for strategic choice and performance. Adm Sci Q 42(4): 654-681

Gong Y, Chang S, Cheung S (2010) High performance work system and collective OCB: A collective social exchange perspective. Hum Resour Manag J 20(2): 119-137

Guthrie JP (2001) High-involvement work practices, turnover, and productivity: Evidence from New Zealand. Acad Manag J 44(1): 180-190

Han JH, Kang S, Oh I-S, Kehoe RR, Lepak DP (2019) The goldilocks effect of strategic human resource management? Optimizing the benefits of a high-performance work system through the dual alignment of vertical and horizontal fit. Acad Manag J 62(5): 1388-1412

Hannah ST, Lester PB (2009) A multilevel approach to building and leading learning organizations. Leadersh Q 20(1): 34-48

Hayes AF, Montoya AK, Rockwood NJ (2017) The analysis of mechanisms and their contingencies: PROCESS versus structural equation modeling. Australas Mark J 25(1): 7681

Hayes AF, Rockwood NJ (2017) Regression-based statistical mediation and moderation analysis in clinical research: Observations, recommendations, and implementation. Behav Res Ther 98: 39-57 
Hayton JC (2005) Promoting corporate entrepreneurship through human resource management practices: A review of empirical research. Hum Resour Manag Rev 15(1): 21-41

Hinkin TR (1998) A brief tutorial on the development of measures for use in survey questionnaires. Organ Res Methods 1(1): 104-121

Hitt MA, Beamish PW, Jackson SE, Mathieu JE (2007) Building theoretical and empirical bridges across levels: Multilevel research in management. Acad Manag J 50(6): 1385-1399

Ho H, Kuvaas B (2020) Human resource management systems, employee well-being, and firm performance from the mutual gains and critical perspectives: The well-being paradox. Hum Resour Manag 59(3): 235-253

Hock-Doepgen M, Clauss T, Kraus S, Cheng C-F (2020) Knowledge management capabilities and organizational risk-taking for business model innovation in SMEs. J Bus Res. doi:https://doi.org/10.1016/j.jbusres.2019.12.001

Hofmann DA, Gavin MB (1998) Centering decisions in hierarchical linear models: Implications for research in organizations. J Manag 24(5): 623-641

Hong Y, Jiang Y, Liao H, Sturman MC (2016) High performance work systems for service quality: Boundary conditions and influence processes. Hum Resour Manag 56(5): 747-767

Howell IP, Dorfman PW, Kerr S (1986) Moderator variables in leadership research. Acad Manag Rev 11(1): 88-102

Hunt SD (1991) Modern marketing theory: Critical issues in the philosophy of marketing science. 
South Western, Cincinnati, OH

Huselid MA (1995) The impact of human resource management practices on turnover, productivity, and corporate financial performance. Acad Manag J 38(3): 635-672

Ireland RD, Hitt MA, Sirmon DG (2003) A model of strategic entrepreneurship: The construct and its dimensions. J Manag 29(6): 963-989

Ivars JVP, Martínez JMC (2015) The effect of high performance work systems on small and medium size enterprises. J Bus Res 68(7): 1463-1465

Jackson SE, Schuler RS (1995) Understanding human resource management in the context of organizations and their environments. Annu Rev Psychol 46(1): 237-264

James LR, Mulaik SA, Brett JM (2006) A tale of two methods. Organ Res Methods 9(2): 233-244

Jiang K, Chuang C-H, Chiao Y-C (2015) Developing collective customer knowledge and service climate: The interaction between service-oriented high-performance work systems and service leadership. J Appl Psychol 100(4): 1089-1106

Jiang K, Hu J, Liu S, Lepak DP (2017) Understanding employees' perceptions of human resource practices: Effects of demographic dissimilarity to managers and coworkers. Hum Resour Manag 56(1): 69-91

Kaufman BE (2015a) Evolution of strategic HRM as seen through two founding books: A 30th anniversary perspective on development of the field. Hum Resour Manag 54(3): 389-407

Kaufman BE (2015b) Market competition, HRM, and firm performance: The conventional 
paradigm critiqued and reformulated. Hum Resour Manag Rev 25(1): 107-125

Kaya N (2006) The impact of human resource management practices and corporate entrepreneurship on firm performance: evidence from Turkish firms. Int J Hum Resour 17(12): 2074-2090

Kenny DA, Kashy D, Bolger N (1998) Data analysis in social psychology, 4th edn. McGraw-Hill, New York, NY

Kesting P, Song LJ, Qin Z, Krol M (2016) The role of employee participation in generating and commercialising innovations: insights from Chinese high-tech firms. Int J Hum Resour 27(10): 1059-1081

Kleinknecht RH (2015) Employee participation in corporate governance: Implications for company resilience. Eur J Ind Relat 21(1): 57-72

Kraus S, Kallmuenzer A, Stieger D, Peters M, Calabrò A (2018) Entrepreneurial paths to family firm performance. J Bus Res 88: 382-387

Kraus S, Roig-Tierno N, Bouncken RB (2019) Digital innovation and venturing: an introduction into the digitalization of entrepreneurship. Rev Manag Sci 13(3): 519-528

Kuratko DF, Hornsby JS, Naffziger DW (1997) An examination of owner's goals in sustaining entrepreneurship. J Small Bus Manag 35(1): 24-33

Kuratko DF, Montagno RV, Hornsby JS (1990) Developing an intrapreneurial assessment instrument for an effective corporate entrepreneurial environment. Strateg Manag J 11: 49- 
Lado AA and Wilson MC (1994) Human resource systems and sustained competitive advantage: a competency-based perspective. Acad Manag Rev 19(4): 699-727

Lane PJ, Lubatkin M (1998) Relative absorptive capacity and interorganizational learning. Strateg Manag J 19(5): 461-477

Laursen K, Foss NJ (2003) New human resource management practices, complementarities and the impact on innovation performance. Cambridge J Reg Econ Soc 27(2): 243-263

Lavie D (2006) The competitive advantage of interconnected firms: An extension of the resourcebased view. Acad Manag Rev 31(3): 638-658

Lepak DP, Snell SA (1999) The human resource architecture: Toward a theory of human capital allocation and development. Acad Manag Rev 24(1): 31-48

Lepak DP, Snell SA (2002). Examining the human resource architecture: The relationships among human capital, employment, and human resource configurations. J Manag 28(4): 517-543

Lepak DP, Takeuchi R., Snell SA (2003) Employment flexibility and firm performance: examining the interaction effects of employment mode, environmental dynamism, and technological intensity. J Manag 29(5): 681-703

Li Y, Wang M, van Jaarsveld DD, Lee GK, Ma DG (2018) From employee-experienced highinvolvement work system to innovation: An emergence-based human resource management framework. Acad Manag J 61(5): 2000-2019 
Liao H, Chuang A (2004) A multilevel investigation of factors influencing employee service performance and customer outcomes. Acad Manag J 47(1): 41-58

Liao H, Toya K, Lepak DP, Hong Y (2009) Do they see eye to eye? Management and employee perspectives of high-performance work systems and influence processes on service quality. J Appl Psychol 94(2): 371-391

Lin Y-T, Liu N-C (2016) High performance work systems and organizational service performance: The roles of different organizational climates. Int J Hosp Manag 55 118-128

Ling YAN, Simsek Z, Lubatkin MH, Veiga JF (2008) Transformational leadership's role in promoting corporate entrepreneurship: Examining the CEO-TMT interface. Acad Manag J 51(3): $557-576$

Liu D, Gong Y, Zhou J, Huang J-C (2017) Human resource systems, employee creativity, and firm innovation: The moderating role of firm ownership. Acad Manag J 60(3): 1164-1188

Liu N-C, Lin Y-T (2019) High-performance work systems, management team flexibility, employee flexibility and service-oriented organizational citizenship behaviors. Int J Hum Resour. doi:10.1080/09585192.2019.1651374

Lu C-M, Chen S-J, Huang P-C, Chien J-C (2015) Effect of diversity on human resource management and organizational performance. J Bus Res 68(4): 857-861

Mallén F, Chiva R, Alegre J, Guinot J (2016) Organicity and performance in excellent HRM organizations: the importance of organizational learning capability. Rev Manag Sci 10(3): 
Marvel MR, Davis JL, Sproul CR (2016) Human capital and entrepreneurship research: A critical review and future directions. Entrep Theory Pract 40(3): 599-626

Mazzei MJ, Flynn CB, Haynie JJ (2016) Moving beyond initial success: Promoting innovation in small businesses through high-performance work practices. Bus Horiz 59(1): 51-60

McEvily B, Perrone V, Zaheer A (2003) Trust as an organizing principle. Organ Sci 14(1): 91-103

McEvily B, Zaheer A (1999) Bridging ties: A source of firm heterogeneity in competitive capabilities. Strateg Manag J 20(12): 1133-1156

Ministry of Economic Affairs (MOEA) (2016) Taiwan Key Innovative Industry - Green energy. Ministry of Economic Affairs (MOEA), Tapei, Taiwan, pp. 8. https://investtaiwan.nat.gov.tw/eBook/eng/eng_5+N/GreenEnergy/mobile/index.html\#p=8 Accessed 12 June 2020

Mom TJM, Chang Y-Y, Cholakova M, Jansen JJP (2019) A Multilevel integrated framework of firm HR practices, individual ambidexterity, and organizational ambidexterity. J Manag 45(7): 3009-3034

Mosey S, Wright M (2007) From human capital to social capital: A longitudinal study of technology-based academic entrepreneurs. Entrep Theory Pract 31(6): 909-935

Mustafa M, Lundmark E, Ramos HM (2016) Untangling the relationship between human resource management and corporate entrepreneurship: The mediating effect of middle managers' 
knowledge sharing. Entrep Res J 6(3): 273-295

Muthén LK, Muthén BO (2015) Mplus: Statistical analysis with latent variables: User's guide, 7th edn. Muthén and Muthén, Los Angeles, CA

Nahapiet J, Ghoshal S (1998) Social capital, intellectual capital, and the organizational advantage. Acad Manag Rev 23(2): 242-266

Nishii LH, Wright PM (2008) Variability within organizations: Implications for strategic human resources management. In: Smith DB (ed.) The people make the place: Dynamic linkages between individuals and organizations. Erlbaum, New York, NY, pp. 225-248

Nyberg AJ, Moliterno TP, Hale DJr, Lepak DP (2014) Resource-based perspectives on unit-level human capital. J Manag 40(1): 316-346

Ostroff C, Bowen DE (2016) Reflections on the 2014 decade award: Is there strength in the construct of HR system strength? Acad Manag Rev 41(2): 196-214

Pak J, Kim S (2018) Team manager's implementation, high performance work systems intensity, and performance: A multilevel investigation. J Manag 44(7): 2690-2715

Palmer C, Fasbender U, Kraus S, Birkner S, Kailer N (2019) A chip off the old block? The role of dominance and parental entrepreneurship for entrepreneurial intention. Rev Manag Sci. doi:10.1007/s11846-019-00342-7

Patel PC, Messersmith JG, Lepak DP (2013) Walking the tight-rope: an assessment of the relationship between high performance work systems and organizational ambidexterity. Acad 
Manag J 56(5): 1420-1442

Payne GT, Moore CB, Griffis SE, Autry CW (2011) Multilevel challenges and opportunities in social capital research. J Manag 37(2): 491-520

Peng MW, Luo Y (2000) Managerial ties and firm performance in a transition economy: The nature of a micro-macro link. Acad Manag J 43(3): 486-501

Pittino D, Visintin F, Lenger T, Sternad D (2016) Are high performance work practices really necessary in family SMEs? An analysis of the impact on employee retention. J Fam Bus Strategy 7(2): 75-89

Podsakoff PM, MacKenzie SB, Lee J-Y, Podsakoff NP (2003) Common method biases in behavioral research: A critical review of the literature and recommended remedies. J Appl Psychol 88(5): 879-903

Pohler D, Luchak A (2015) Are unions good or bad for organizations? The moderating role of management's response. Eur J Ind Relat 53(3): 423-459

Prieto-Pastor I, Martin-Perez V (2015) Does HRM generate ambidextrous employees for ambidextrous learning? The moderating role of management support. Int J Hum Resour 26(5): 589-615

Reed KK, Lubatkin M, Srinivasan N (2006) Proposing and testing an intellectual capital-based view of the firm. J Manag Stud 43(4): 867-893

Sáa-Pérez PD, Garcia-Falcon JM (2002) A resource-based view of human resource management 
and organizational capabilities development. Inter J Hum Resour Manag 13(1): 123-140

Salas-Vallina A, Alegre J, López-Cabrales Á (2020) The challenge of increasing employees' wellbeing and performance: How human resource management practices and engaging leadership work together toward reaching this goal. Hum Resour Manag. doi:10.1002/hrm.22021

Schmelter R, Mauer R, Börsch C, Brettel M (2010) Boosting corporate entrepreneurship through HRM practices: Evidence from German SMEs. Hum Resour Manag 49(4): 715-741

Schuler RS (1986) Fostering and facilitating entrepreneurship in organizations: Implications for organization structure and human resource management practices. Hum Resour Manag 25(4): 607-629

Schuler RS, MacMillan IC (1984) Gaining competitive advantage through human resource management practices. Hum Resour Manag 23(3): 241-255

Schumpeter JA (1934) The theory of economic development: An inquiry into profits, capital, credit, interest, and the business cycle. Harvard University Press, Cambridge, MA

Seeck H, Diehl M-R (2017) A literature review on HRM and innovation - taking stock and future directions. Int J Hum Resour 28(6): 913-944

Semrau T, Ambos T, Kraus S (2016) Entrepreneurial orientation and SME performance across societal cultures: An international study. J Bus Res 69(5): 1928-1932

Shane S, Venkataraman S (2000) The promise of entrepreneurship as a field of research. Acad Manag Rev 25(1): 217-226 
Shin D, Konrad AM (2017). Causality between high-performance work systems and organizational performance. J Manag 43(4): 973-997

Shipilov A, Godart FC, Clement J (2017) Which boundaries? How mobility networks across countries and status groups affect the creative performance of organizations. Strateg Manag J 38(6): 1232-1252

Simsek Z (2007) CEO tenure and organizational performance: An intervening model. Strateg Manag J 28(6): 653-662

Simsek Z, Heavey C (2011) The mediating role of knowledge-based capital for corporate entrepreneurship effects on performance: A study of small- to medium-sized firms. Strateg Entrep J 5(1): 81-100

Spiro RL, Weitz BA (1990) Adaptive selling: Conceptualization, measurement, and nomological validity. J Mark Res 27(1): 61-69

Stam W, Elfring T (2008) Entrepreneurial orientation and new venture performance: The moderating role of intra- and extraindustry social capital. Acad Manag J 51(1): 97-111

Stuart TE, Hoang H, Hybels RC (1999) Interorganizational endorsements and the performance of entrepreneurial ventures. Adm Sci Q 44(2): 315-349

Su Z-X, Wright PM, \& Ulrich MD (2018) Going beyond the SHRM paradigm: Examining four approaches to governing employees. J Manag 44(4): 1598-1619

Subramaniam M, Youndt MA (2005) The influence of intellectual capital on the types of 
innovative capabilities. Acad Manag J 48(3): 450-463

Sullivan DM, Marvel MR (2011) Knowledge acquisition, network reliance, and early-stage technology venture outcomes. J Manag Stud 48(6): 1169-1193

Tang G, Wei L-Q, Snape E, Ng YC (2015) How effective human resource management promotes corporate entrepreneurship: evidence from China. Int J Hum Resour 26(12): 1586-1601

Tsao C-W, Chen S-J, Wang Y-H (2016) Family governance oversight, performance, and high performance work systems. J Bus Res 69(6): 2130-2137

Unger JM., Rauch A, Frese M, Rosenbusch N (2011) Human capital and entrepreneurial success: A meta-analytical review. J Bus Ventur 26(3): 341-358

von Bonsdorff ME, Zhou L, Wang M, Vanhala S, von Bonsdorff MB, Rantanen T (2016) Employee age and company performance: An integrated model of aging and human resource management practices. J Manag 44(8): 3124-3150

Wei LQ, Lau CM (2008) The impact of market orientation and strategic HRM on firm performance: The case of Chinese enterprises. Int Bus Rev 39(6): 980-995

Wernerfelt B (1984) A resource-based view of the firm. Strateg Manag J 5(2): 171-180

Wiedemann AU, Schüz B, Sniehotta F, Scholz U, Schwarzer R (2009) Disentangling the relation between intentions, planning, and behaviour: A moderated mediation analysis. Psychol Health 24(1): 67-79

Wright PM, Dunford BB, Snell SA (2001) Human resources and the resource based view of the 
firm. J Manag 27(6): 701-721

Wright PM, McMahan GC (1992) Theoretical perspectives for strategic human resource management. J Manag 18(2): 295-320

Wright PM, Ulrich MD (2017) A road well traveled: The past, present, and future journey of strategic human resource management. Annu Rev Organ Psychol Organ Behav 4(1): 45-65

Yli-Renko H, Autio E, Sapienza HJ (2001) Social capital, knowledge acquisition, and knowledge exploitation in young technology-based firms. Strateg Manag J 22(6-7): 587-613

Zahra SA (1996) Technology strategy and new venture performance: A study of corporatesponsored and independent biotechnology ventures. J Bus Ventur 11(4): 289-321

Zhang Z, Jia M (2010) Using social exchange theory to predict the effects of high-performance human resource practices on corporate entrepreneurship: Evidence from China. Hum Resour Manag 49(4): 743-765

Zhou Y, Fan X, Son J (2019) How and when matter: Exploring the interaction effects of highperformance work systems, employee participation, and human capital on organizational innovation. Hum Resour Manag 58(3): 253-268 
Table 1 Comparison of measurement models

\begin{tabular}{cccccccccc}
\hline Model & $\begin{array}{c}\text { No. of } \\
\text { factors }\end{array}$ & $\chi^{\mathbf{2}}$ & $\boldsymbol{d} \boldsymbol{f}$ & $\Delta \boldsymbol{\chi}^{\mathbf{2}}$ & $\boldsymbol{\Delta} \boldsymbol{d f}$ & RMSEA & CFI & GFI & TLI \\
\hline Hypothesized & Four $^{\mathrm{a}}$ & 401.96 & 164 & - & - & 0.08 & 0.95 & 0.90 & 0.94 \\
1 & Three $^{\mathrm{b}}$ & 497.12 & 165 & $95.16^{* * *}$ & 1 & 0.12 & 0.85 & 0.74 & 0.84 \\
2 & Three $^{\mathrm{c}}$ & 477.86 & 165 & $75.90^{* * *}$ & 1 & 0.12 & 0.85 & 0.74 & 0.84 \\
3 & Three $^{\mathrm{d}}$ & 476.90 & 165 & $74.94^{* * *}$ & 1 & 0.12 & 0.85 & 0.75 & 0.84 \\
4 & Three $^{\mathrm{e}}$ & 477.08 & 165 & $75.12^{* * *}$ & 1 & 0.12 & 0.85 & 0.75 & 0.84 \\
5 & Three $^{\mathrm{f}}$ & 486.70 & 165 & $84.74^{* * *}$ & 1 & 0.12 & 0.85 & 0.74 & 0.84 \\
6 & Three $^{\mathrm{g}}$ & 474.28 & 165 & $72.32^{* * *}$ & 1 & 0.12 & 0.85 & 0.74 & 0.84 \\
7 & Two $^{\mathrm{h}}$ & 558.73 & 167 & $156.77^{* * *}$ & 3 & 0.13 & 0.84 & 0.73 & 0.83 \\
8 & Two $^{\mathrm{i}}$ & 566.46 & 167 & $164.50^{* * *}$ & 3 & 0.13 & 0.84 & 0.73 & 0.83 \\
9 & Two $^{\mathrm{j}}$ & 580.47 & 167 & $178.51^{* * *}$ & 3 & 0.13 & 0.84 & 0.73 & 0.83 \\
10 & Two $^{\mathrm{k}}$ & 555.56 & 167 & $153.60^{* * *}$ & 3 & 0.13 & 0.84 & 0.73 & 0.83 \\
11 & One $^{1}$ & 664.93 & 170 & $262.97^{* * *}$ & 6 & 0.14 & 0.83 & 0.72 & 0.82 \\
\hline
\end{tabular}

Note. ${ }^{a}$ firm-level high-performance work systems (HPWS); firm-level bridging ties (BT); unit-level corporate entrepreneurship (CE); dyad-level human capital (HC). ${ }^{b} \mathrm{HPWS}+\mathrm{BT}$; CE; HC. ${ }^{\mathrm{C}} \mathrm{HPWS}+\mathrm{CE}$; BT; HC. ${ }^{d} \mathrm{HPWS}+\mathrm{HC} ; \mathrm{BT} ;$ CE. ${ }^{\mathrm{e}} \mathrm{BT}+\mathrm{CE}$; HPWS; HC. ${ }^{\mathrm{f}} \mathrm{BT}+\mathrm{HC}$; HPWS; CE. ${ }^{\mathrm{g}} \mathrm{CE}+\mathrm{HC}$; HPWS; BT. ${ }^{\mathrm{h}} \mathrm{HPWS}+\mathrm{BT}+\mathrm{CE} ; \mathrm{HC} .{ }^{\mathrm{i}} \mathrm{HPWS}+\mathrm{BT}+\mathrm{HC} ; \mathrm{CE} .{ }^{\mathrm{j}} \mathrm{HPWS}+\mathrm{CE}+\mathrm{HC} ; \mathrm{BT} .{ }^{k} \mathrm{BT}+\mathrm{CE}+\mathrm{HC} ; \mathrm{HPWS}$. ${ }^{1} \mathrm{HPWS}+\mathrm{BT}+\mathrm{CE}+\mathrm{HC}$

${ }^{*} p<.05,{ }^{* *} p<.01,{ }^{* * *} p<.001$.

Table 2 Comparison of structural models

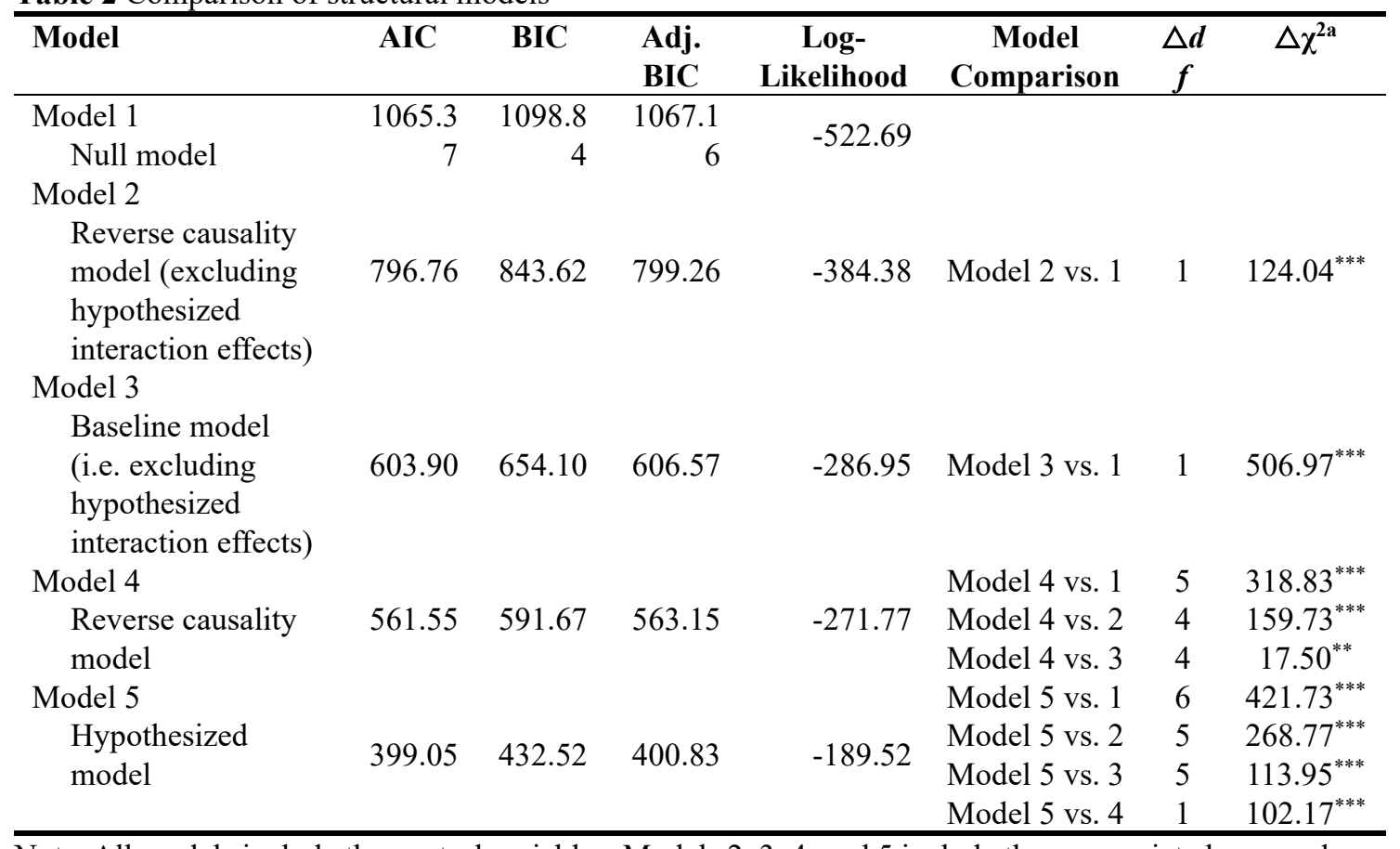

Note: All models include the control variables. Models 2, 3, 4, and 5 include the appropriate lower order terms for the tested interactions. AIC $=$ Akaike information criterion; BIC $=$ Bayesian information criterion; Adj. BIC = sample-size adjusted Bayesian information criterion.

a Satorra-Bentler scaled chi-square difference test. ${ }^{*} p<.05 .{ }^{* *} p<.01 .{ }^{* * *} p<.001$. 
Table 3 Means, standard deviations and correlations

\begin{tabular}{|c|c|c|c|c|c|c|c|c|c|c|c|c|c|c|}
\hline & Mean & SD & 1 & 2 & 3 & 4 & 5 & 6 & 7 & 8 & 9 & 10 & 11 & 12 \\
\hline 1. Unit size & 59.48 & 153.26 & - & & & & & & & & & & & \\
\hline 2. Unit age & 19.63 & 13.38 & $0.10^{* *}$ & - & & & & & & & & & & \\
\hline $\begin{array}{l}\text { 3. Manager tenure in the } \\
\text { current job }\end{array}$ & 9.14 & 6.24 & 0.04 & $0.20^{* * *}$ & - & & & & & & & & & \\
\hline 4. Dyad-level human capital & 5.30 & 0.67 & $0.21^{* * *}$ & -0.00 & -0.01 & - & & & & & & & & \\
\hline $\begin{array}{l}\text { 5. Unit-level corporate } \\
\text { entrepreneurship }\end{array}$ & 4.89 & 0.73 & $0.19^{* * *}$ & -0.02 & $-0.15^{* * *}$ & $0.51^{* * *}$ & - & & & & & & & \\
\hline 6. Firm size & 4072.71 & 10887.31 & $0.45^{* * *}$ & $0.13^{* * *}$ & -0.01 & $0.33^{* * *}$ & $0.24^{* * *}$ & - & & & & & & \\
\hline 7. Firm age & 27.70 & 18.98 & $0.15^{* * *}$ & $0.54^{* * *}$ & $0.27^{* * *}$ & 0.07 & 0.04 & $0.21^{* * *}$ & - & & & & & \\
\hline 8. TMT size & 92.32 & 213.62 & $0.11^{* *}$ & $0.24^{* * *}$ & 0.01 & $0.19^{* * *}$ & $0.18^{* * *}$ & $0.48^{* * *}$ & $0.23^{* * *}$ & - & & & & \\
\hline $\begin{array}{l}\text { 9. Firm-level Environmental } \\
\text { uncertainty }\end{array}$ & 5.40 & 0.56 & $0.23^{* * *}$ & $0.25^{* * *}$ & $0.09^{*}$ & $0.38^{* * *}$ & $0.29^{* * *}$ & $0.37^{* * *}$ & $0.20^{* * *}$ & $0.29^{* * *}$ & - & & & \\
\hline 10. Sector & 0.89 & 0.32 & $-0.27^{* * *}$ & 0.03 & -0.02 & $-0.24^{* * *}$ & -0.02 & $-0.36^{* * *}$ & $-0.14^{* *}$ & $-0.15^{* * *}$ & $-0.19^{* * *}$ & - & & \\
\hline 11. Firm-level HPWS & 5.39 & 0.57 & $0.28^{* * *}$ & -0.04 & 0.05 & $0.59^{* * *}$ & $0.46^{* * *}$ & $0.27^{* * *}$ & 0.06 & $0.20^{* * *}$ & $0.30^{* * *}$ & $-0.23^{* * *}$ & - & \\
\hline 12. Firm-level bridging ties & 4.81 & 0.75 & $0.22^{* * *}$ & -0.01 & $-0.18^{* * *}$ & $0.43^{* * *}$ & $0.50^{* * *}$ & $0.22^{* * *}$ & -0.02 & $0.16^{* * *}$ & $0.24^{* * *}$ & $-0.20^{* * *}$ & $0.39^{* * *}$ & - \\
\hline
\end{tabular}
${ }^{*} p<0.10,{ }^{* *} p<0.05,{ }^{* * *} p<0.01$.

TMT, Top management team; HPWS, high-performance work systems. 
Table 4 Hierarchical linear modelling results: Effects of firm-level high-performance work systems on unit-level corporate entrepreneurship

\begin{tabular}{|c|c|c|c|c|}
\hline Level and variables & $\begin{array}{l}\text { HC } \\
\text { (Model 1) }\end{array}$ & $\begin{array}{l}\text { CE } \\
\text { (Model 2) }\end{array}$ & $\begin{array}{l}\text { CE } \\
\text { (Model 3) }\end{array}$ & $\begin{array}{l}\text { CE } \\
\text { (Model 4) }\end{array}$ \\
\hline \multicolumn{5}{|l|}{ Unit/dyad-level (Level 1) $(\mathrm{n}=$} \\
\hline \multicolumn{5}{|l|}{ 210) } \\
\hline Intercept & $-0.66^{* *}$ & $-1.61^{* * *}$ & $-1.22^{* * *}$ & $3.25^{* * *}$ \\
\hline Unit size & $-0.00^{* * *}$ & -0.00 & 0.00 & 0.00 \\
\hline Unit age & 0.00 & $-0.01^{* * *}$ & $-0.01^{* * *}$ & $-0.01^{* * *}$ \\
\hline $\begin{array}{l}\text { Manager tenure in the current } \\
\text { job }\end{array}$ & 0.00 & $-0.02^{* * *}$ & $-0.03^{* * *}$ & -0.02 \\
\hline Dyad-level HC & & & $0.49^{* * *}$ & $0.47^{* * *}$ \\
\hline \multicolumn{5}{|l|}{ Firm-level (Level 2) $(n=96)$} \\
\hline Firm size (log of employees) & $0.11^{* * *}$ & 0.06 & -0.00 & $-0.05^{* *}$ \\
\hline Firm age & $-0.01^{* * *}$ & $0.00^{* *}$ & $0.01^{* * *}$ & $0.01^{* * *}$ \\
\hline TMT size $(\log$ of TMT) & $-0.08^{* * *}$ & 0.01 & $0.05^{*}$ & $0.08^{* * *}$ \\
\hline Environmental uncertainty & $0.17^{* * *}$ & $0.22^{* *}$ & $0.14^{* *}$ & $0.26^{* * *}$ \\
\hline Sector & 0.08 & $0.57^{* * *}$ & $0.52^{* * *}$ & $0.50^{* * *}$ \\
\hline HPWS & $0.88^{* * *}$ & $0.87^{* * *}$ & $0.44^{* * *}$ & 0.39 \\
\hline BT & & & & $0.80^{* *}$ \\
\hline $\mathrm{HPWS} \times \mathrm{BT}$ & & & & -0.07 \\
\hline \multicolumn{5}{|l|}{ Cross level } \\
\hline Dyad-level HC $\times$ firm-level BT & & & & $0.10^{* *}$ \\
\hline Pseudo $R^{2}$ & 0.97 & 0.78 & 0.21 & 0.24 \\
\hline
\end{tabular}

HPWS, high-performance work systems; BT, bridging ties; HC, human capital; CE, corporate entrepreneurship;

TMT, top management team. 
Table 5 Additional analysis - Two-level moderated mediation model: Paths, estimate, and their significance ${ }^{\mathrm{a}}$

\begin{tabular}{|c|c|c|c|}
\hline \multirow[t]{2}{*}{ Part A: Direct effect (unstandardized estimates) } & \multirow[t]{2}{*}{ Estimate $\left(\mathrm{SE}^{\mathrm{c}}\right)$} & \multicolumn{2}{|c|}{ Monte Carlo Simulation $^{\mathrm{d}}$} \\
\hline & & $\mathbf{L L C I}^{\mathrm{e}}$ & $\mathbf{U L C I}^{\mathrm{e}}$ \\
\hline Firm-level HPWS $\rightarrow$ Dyad-level HC & $0.99^{* * *}(0.05)$ & 0.90 & 1.08 \\
\hline Firm-level HPWS $\rightarrow$ Unit-level CE & $0.71^{*}(0.28)$ & 0.24 & 1.18 \\
\hline Dyad-level HC $\rightarrow$ Unit-level CE & $0.69^{* * *}(0.13)$ & 0.48 & 0.90 \\
\hline Part B: Moderated effect (unstandardized estimates) & Estimate (SE) & LLCI & ULCI \\
\hline Firm-level BT $\rightarrow$ Unit-level CE & $0.69^{* *}(0.25)$ & 0.27 & 1.11 \\
\hline Dyad-level HC $\times$ Firm-level BT $\rightarrow$ Unit-level CE & $0.11^{* *}(0.04)$ & 0.04 & 0.18 \\
\hline Part C: Indirect effect (unstandardized estimates) & Estimate (SE) & LLCI & ULCI \\
\hline Firm-level HPWS $\rightarrow$ Dyad-level HC $\rightarrow$ Unit-level CE & $0.68^{* * *}(0.12)$ & 0.48 & 0.88 \\
\hline $\begin{array}{l}\text { Part D: Moderated mediation effect (unstandardized } \\
\text { estimates) }\end{array}$ & Estimate (SE) & LLCI & ULCI \\
\hline $\begin{array}{l}\text { Firm-level HPWS } \rightarrow \text { Dyad-level HC } \times \text { Firm-level BT } \rightarrow \\
\text { Unit-level CE }\end{array}$ & $0.11^{* *}(0.04)$ & 0.05 & 0.17 \\
\hline $\begin{array}{l}\text { Part E: Unit-level CE } \\
\text { Moderator (Firm-level BT) }\end{array}$ & Estimate & LLCI & ULCI \\
\hline $\begin{array}{cc}-2 \\
-1 \\
0 \\
1 \\
2 \\
\end{array}$ & $\begin{array}{c}0.07 \\
0.34 \\
0.61^{* * *} \\
0.89^{* * *} \\
1.16^{* * *} \\
\end{array}$ & $\begin{array}{l}-0.75 \\
-0.28 \\
0.09 \\
0.27 \\
0.39 \\
\end{array}$ & $\begin{array}{l}0.89 \\
0.96 \\
1.13 \\
1.51 \\
1.93 \\
\end{array}$ \\
\hline \multicolumn{4}{|c|}{$\begin{array}{l}\mathrm{a}=210 \text { at the unit/dyad level (level } 1) ; \mathrm{n}=96 \text { at the firm level (level } 2) .{ }^{\mathrm{b} *} p<.05,{ }^{* * *} p<.01,{ }^{* * *} p<.001 .{ }^{\mathrm{c}} \mathrm{SE}= \\
\text { standard error of estimate. }{ }^{\mathrm{d}} 50000 \text { times. }{ }^{\mathrm{e}} \mathrm{CI}=\text { confidence interval; LLCI }=\text { lower level of the } 95 \% \text { confidence } \\
\text { interval; ULCI = upper level of the } 95 \% \text { confidence interval. } \\
\text { Notes: HPWS, high-performance work systems; BT, bridging ties; HC, human capital; CE, corporate } \\
\text { entrepreneurship. } \\
\text { Table } 6 \text { Firm-level HPWS endogeneity tests results }\end{array}$} \\
\hline \multicolumn{4}{|c|}{ Firm-level HPWS endogeneity test } \\
\hline $\begin{array}{c}\text { Test } \\
\text { Durbin } \\
\text { Wu-Hausman }\end{array}$ & 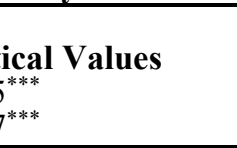 & & $\begin{array}{l}\text { lues } \\
396 \\
46\end{array}$ \\
\hline
\end{tabular}

*** Significant at $1^{*}$ level. Notes: HPWS, high-performance work systems; CE, corporate entrepreneurship. Table 7 Firm-level bridging ties endogeneity tests results

\begin{tabular}{ccc}
\hline & Firm-level bridging ties Endogeneity Test \\
\hline Test & Unit-level CE & P-Values \\
Durbin & Calculated Critical Values & 0.87928 \\
Wu-Hausman & $0.02313^{* * *}$ & 0.87768 \\
\hline
\end{tabular}

${ }^{* * *}$ Significant at $1 *$ level. Notes: HPWS, high-performance work systems; CE, corporate entrepreneurship.

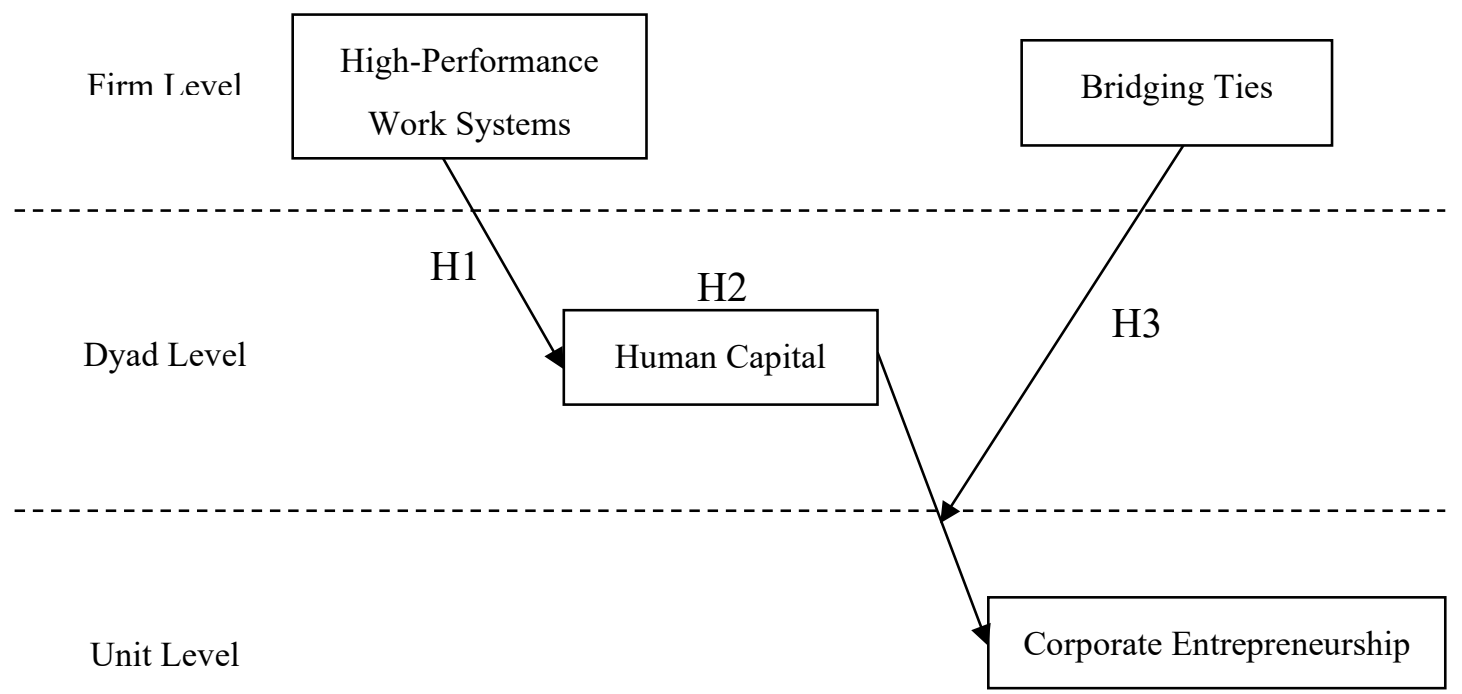

Fig. 1 An integrative multilevel model of firm-level high-performance work systems (HPWS), dyad-level human capital, firm-level bridging ties and unit-level corporate entrepreneurship 


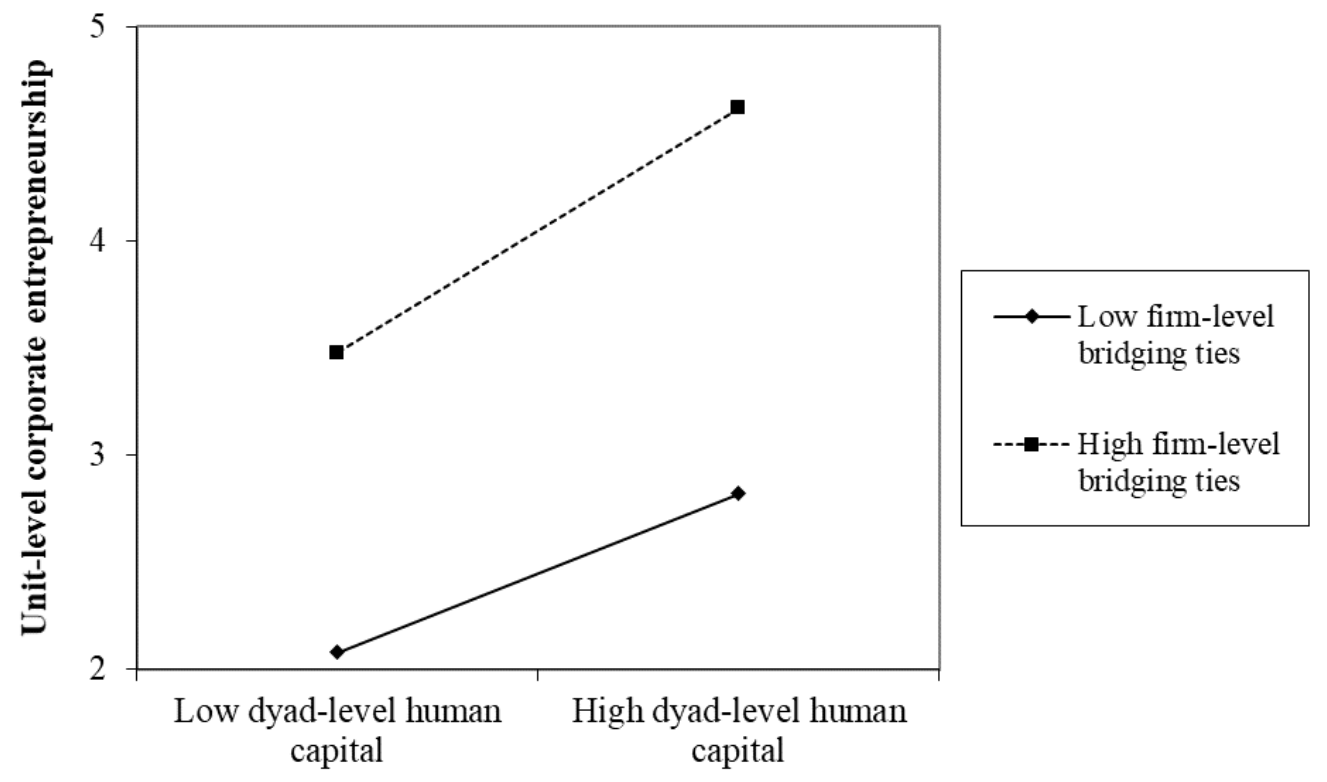

Fig. 2 Indirect effect of firm-level high-performance work systems (HPWS) (via dyad-level human capital) on unit-level corporate entrepreneurship at low and high levels of firm-level bridging ties

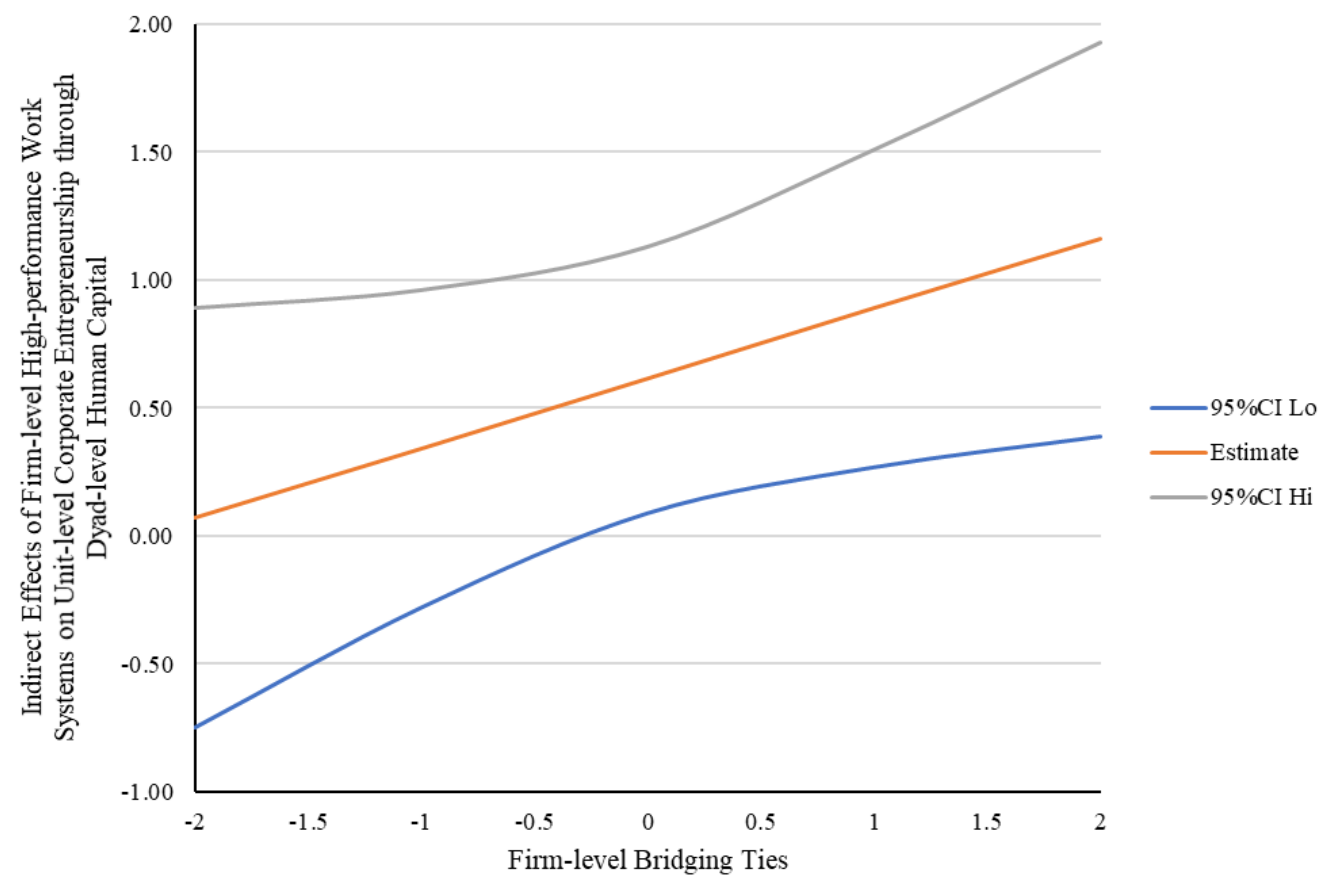

Fig. 3 Second stage moderated mediation effect of firm-level high-performance work systems (HPWS) on unitlevel corporate entrepreneurship at low and high levels of firm-level bridging ties through dyad-level human capital 


\section{Appendix: Measurement instrument and exploratory factor analysis results}

1. Unit-level corporate entrepreneurship

\begin{tabular}{|c|c|c|c|}
\hline \multirow[b]{2}{*}{ Dimensions } & \multicolumn{3}{|c|}{ Factors } \\
\hline & 1 & 2 & 3 \\
\hline \multicolumn{4}{|l|}{ Innovation } \\
\hline $\begin{array}{l}\text { 1. spending heavily (well above the industry average) on product } \\
\text { development }\end{array}$ & .74 & .29 & .12 \\
\hline 2.introducing a large number of new products to the market & .78 & .18 & .12 \\
\hline 3. acquiring significantly more patents than its major competitors & .85 & .10 & .20 \\
\hline 4. pioneering the development of breakthrough innovations in its industry & .85 & .17 & .20 \\
\hline 5. spending on new product development initiatives & .69 & .21 & .23 \\
\hline \multicolumn{4}{|l|}{ Venturing } \\
\hline 6. entering new markets & .25 & .69 & .20 \\
\hline 7. acquiring companies in different industries & .24 & .48 & .27 \\
\hline 8. establishing or sponsoring new ventures & .22 & .85 & .12 \\
\hline 9. finding new niches in current markets & .23 & .78 & .15 \\
\hline 10. financing start-up business activities & .29 & .80 & .16 \\
\hline 11. creating new semi-autonomous and autonomous units & .06 & .66 & .20 \\
\hline \multicolumn{4}{|l|}{ Strategic renewal } \\
\hline 12. divesting unprofitable business units & .13 & .17 & .78 \\
\hline 13. changing its competitive approach & .19 & .22 & .82 \\
\hline $\begin{array}{l}\text { 14. reorganizing operations, units, and divisions to ensure increased } \\
\text { coordination and communication }\end{array}$ & .28 & .17 & .78 \\
\hline 15. redefining the industries in which it competes & .25 & .13 & .53 \\
\hline 16. introducing innovative human resource programs & .29 & .21 & .54 \\
\hline 17. first in the industry to introduce new business concepts and practices & .34 & .32 & .47 \\
\hline Eigenvalue & 8.61 & 1.59 & 1.32 \\
\hline Percentage of variance explained & 27.94 & 21.56 & 18.26 \\
\hline
\end{tabular}

Note. The three factors explained $67.76 \%$ of the variance.

2. Firm-level HPWS

\begin{tabular}{|c|c|c|c|c|c|c|c|c|}
\hline \multirow[b]{2}{*}{ Type of HPWS } & \multicolumn{8}{|c|}{ Factors } \\
\hline & 1 & 2 & 3 & 4 & 5 & 6 & 7 & 8 \\
\hline \multicolumn{9}{|l|}{ Training } \\
\hline $\begin{array}{l}\text { 1. The formal orientation programs to } \\
\text { new managers are helpful for them } \\
\text { perform their job. }\end{array}$ & .82 & .29 & .03 & -.06 & .11 & .04 & .11 & .04 \\
\hline $\begin{array}{l}\text { 2. Training programs other than } \\
\text { corporate-wide orientation program } \\
\text { are effective in teaching managers } \\
\text { the skills they need in serving } \\
\text { customers. }\end{array}$ & .87 & .21 & .08 & .05 & .19 & .13 & -.06 & .07 \\
\hline $\begin{array}{l}\text { 3. Our training programs effectively } \\
\text { prepare managers to provide high } \\
\text { quality customer service. }\end{array}$ & .72 & .05 & .29 & .17 & .26 & .17 & .04 & .10 \\
\hline $\begin{array}{l}\text { 4. Managers will normally go through } \\
\text { training programs to improve their } \\
\text { customer service skills every few } \\
\text { years. }\end{array}$ & .66 & .20 & .25 & .24 & .25 & .19 & -.08 & .22 \\
\hline $\begin{array}{l}\text { 5. Managers are adequately trained to } \\
\text { handle the introduction of new } \\
\text { products and services. }\end{array}$ & .64 & .19 & .19 & .15 & .23 & .16 & -.04 & .29 \\
\hline $\begin{array}{l}\text { 6. This firm assists managers to join } \\
\text { the customer service training } \\
\text { program provided by the } \\
\text { Headquarter. }\end{array}$ & .61 & .28 & .17 & .20 & .28 & .10 & -.02 & .21 \\
\hline
\end{tabular}


Information sharing

7. The findings from employee surveys are communicated to managers of this firm.

8. The findings from customer surveys are communicated to managers of this firm.

9. All business memos of this firm are shared with managers.

10. Customers' suggestions for how to improve service quality are shared with managers.

11. Information about how well the firm is performing financially is shared with managers.

12. Complaints or negative comments about this firm's service from external customers are shared with managers.

13. Managers have the manuals and individual computer they need for the network systems they work with.

14. Managers have, or have access to, the product and policy information they need to do their work.

Interdepartmental service

15. Units of this firm cooperate well with each other.

16. In this firm, managers in one department get the needed materials from other departments in a timely fashion.

Teams and participation

17. The development of work teams among Managers is an important element of this firm's strategy.

18. This firm supports team development and training for managers.

19. This firm asks managers for their suggestions on how to improve customer service.

20. Managers' suggestions on customer service are implemented in full or in part within this firm.

21 . Decision-making by managers is encouraged in this firm.

Service discretion

22. Managers have the authority to resolve customer complaints on $.14 \quad .25$

.5

20

68

$.02 \quad .23$

$\begin{array}{llll}.01 & .02 & .10 & .04\end{array}$

$\begin{array}{llllllll}.03 & .59 & .20 & .19 & .20 & .20 & -.07 & .20\end{array}$

$\begin{array}{lllllll}.76 & .06 & .05 & .29 & .06 & .09 & -.04\end{array}$

$\begin{array}{llllll}.16 & .14 & .28 & .16 & -.01 & .29\end{array}$

$\begin{array}{llllllll}.04 & .19 & \mathbf{8 0} & .21 & .25 & .04 & .08 & .10\end{array}$
their own.

23. Managers have the discretion to customize the service offering to meet customer needs

$\begin{array}{llllllll}.26 & .29 & -.05 & .66 & .21 & .00 & -.06 & .23 \\ .28 & .29 & .11 & .58 & .29 & .26 & .15 & .20 \\ & & & & & & & \\ .24 & .21 & .13 & .57 & .22 & .10 & -.03 & .21 \\ -.08 & .23 & -.03 & .62 & .15 & .16 & .06 & .11 \\ .11 & .29 & .10 & .66 & .02 & .25 & .12 & .01 \\ & & & & & & & \\ .08 & .17 & .27 & .16 & .60 & .20 & .15 & -.09 \\ & & & & & & & \\ .05 & .07 & .17 & .22 & . \mathbf{7 6} & .25 & .05 & .08 \\ & & & & & & & \end{array}$


24. Managers may decide how to personalize the service for the customer.

25. Managers may use a wide variety of strategies to satisfy the customer.

26. Managers are encouraged to adapt their behaviors to the needs of the customer.

Performance appraisals

27. A track record of the managers' courteous service to customers.

28. The ability of the managers to resolve customer complaints or service problems in an efficient manner.

29 . The ability of the managers to innovatively deal with unique situations and/or meet customer needs.

30. The managers' commitment to customers.

31. This firm pays above market wages to managers. Pay

32. The way in which managers in this firm are compensated encourages them to adopt a long-term focus.

33. Managers' pay is tied to the quality of service they provide.

Job design for quality work

34. Fostering involvement in decision-making of managers is an important element of the corporate strategy.

35. Many managers in this firm perform simple and repetitive tasks as part of their work.

36. Providing managers with high quality jobs (i.e. jobs that are challenging, fulfilling, etc.) is a priority in this firm.

37. Managers of this firm are given lots of opportunity to decide how to do their work.

Eigenvalue

$.06 \quad .07$

$.17 \quad .25$

.79

$.18 \quad .08$

$\begin{array}{llllllllll}.20 & .16 & .22 & .20 & .64 & .26 & -.17 & .22\end{array}$

$\begin{array}{lllllllll}.21 & .21 & .16 & .19 & .57 & .25 & -.13 & .19\end{array}$

$\begin{array}{llllllll}.03 & .07 & .05 & .13 & .23 & .76 & .09 & .17 \\ .27 & .13 & .07 & .21 & .29 & .56 & .04 & .18\end{array}$

$\begin{array}{lllllllll}.29 & .10 & .09 & .27 & .23 & .52 & -.01 & .25\end{array}$

$\begin{array}{llllllll}.21 & .12 & .05 & .23 & .25 & .76 & -.04 & .14 \\ -.05 & .11 & .12 & .21 & -.12 & .78 & .00 & .13\end{array}$

$\begin{array}{llllllll}.12 & .08 & .19 & .13 & .29 & .12 & .79 & .09\end{array}$

$\begin{array}{lllllllll}.12 & .13 & .24 & -.01 & .29 & .29 & .70 & .06\end{array}$

$\begin{array}{llllllllll}.24 & .20 & .13 & .22 & .28 & .27 & -.06 & .50\end{array}$

$\begin{array}{rrrrrrrr}-.05 & -.02 & .04 & -.27 & .02 & -.09 & -.09 & \mathbf{. 8 9} \\ .18 & .10 & -.05 & .28 & .21 & .00 & .08 & .51\end{array}$

$\begin{array}{lllllllll}-.04 & .27 & .19 & .10 & .21 & .29 & .28 & .61\end{array}$

Percentage of variance explained

\begin{tabular}{llllllll}
1.55 & 2.11 & 1.06 & 2.83 & 17.13 & 1.26 & 1.02 & 1.42 \\
\hline
\end{tabular}

$\begin{array}{llllllll}9.19 & 11.53 & 6.98 & 13.01 & 16.01 & 7.34 & 3.12 & 8.96\end{array}$

Note. The eight factors explained $76.14 \%$ of the variance. HPWS, high-performance work systems.

3. Firm-level bridging ties

\begin{tabular}{lcc}
\multicolumn{1}{c}{ Dimensions } & \multicolumn{2}{c}{ Factors } \\
\cline { 2 - 3 } Ties with managers at other firms & 1 & 2 \\
1.top managers at buyer firms & .84 & .28 \\
2.top managers at supplier firms & .93 & .10 \\
3.top managers at competitor firms & .60 & .32
\end{tabular}


4. political leaders in various levels of the government

5. officials in industrial bureaus

6. officials in regulatory and supporting organizations such as tax bureaus, state

banks, commercial administration bureaus, and the like

Eigenvalue

Percentage of variance explained

Note. The two factors explained $82.41 \%$ of the variance.

4. Dyad-level human capital

(1) Manager rating

\begin{tabular}{lc}
\hline \multicolumn{1}{c}{ Dimensions } & Factors \\
\cline { 2 - 2 } 1. Our employees are highly skilled. & 1 \\
2. Our employees are widely considered the best in our industry. & .85 \\
3. Our employees are creative and bright. & .90 \\
4. Our employees are experts in their particular jobs and functions. & .92 \\
5.Our employees develop new ideas and knowledge. & .93 \\
Eigenvalue & .89 \\
Percentage of variance explained & 4.02 \\
\hline
\end{tabular}

Note. The one factor explained $80.47 \%$ of the variance.

(2) Employee rating

\begin{tabular}{lc}
\hline \multicolumn{1}{c}{ Dimensions } & Factors \\
\cline { 2 - 2 } 1. Our employees are highly skilled. & 1 \\
2.Our employees are widely considered the best in our industry. & .78 \\
3. Our employees are creative and bright. & .88 \\
4. Our employees are experts in their particular jobs and functions. & .89 \\
5. Our employees develop new ideas and knowledge. & .90 \\
Eigenvalue & .86 \\
Percentage of variance explained & 3.73 \\
\hline
\end{tabular}

Note. The one factor explained $74.58 \%$ of the variance. 